\title{
ZAWARTOŚĆ I KATALOG RUBRYCEL DIECEZJI KRAKOWSKIEJ Z LAT 1735-1811 ZNAJDUJĄCYCH SIE W KSIĘGOZBIORZE PODRĘCZNYM ARCHIWUM KURII METROPOLITALNEJ W KRAKOWIE
}

\section{Streszczenie}

W zasobach Archiwum Kurii Metropolitalnej w Krakowie znajduje się znaczny zbiór kalendarzy liturgicznych diecezji krakowskiej. Z pierwszej połowy XVIII wieku zachowały się tylko trzy egzemplarze $(1735,1738$ i 1745). Od 1750 r. zbiór jest prawie kompletny. Brakuje tylko dziewięciu roczników z lat: 1753-1756, 1775, 1779, 1781, 1784, 1789 oraz ośmiu z początku XIX wieku: 1802-1804, 1806, 1808-1810, 1839.

Ze względu na powszechność korzystania z kalendarza przez księży zaczęto dołączać do rubryceli: informacje o nabożeństwach i praktykach obowiązujących w całej diecezji, zarządzenia władz duchownych i świeckich (szczególnie dotyczące zmian przepisów liturgicznych i postnych). Do ostatnich dekad XIX wieku nie wypracowano reguł redagowania dodatków do rubrycel. W jednych tomach można znaleźć wiele szczegółowych przepisów liturgicznych, nigdzie niepublikowanych poza nimi komunikatów, rozporządzeń i krótkich listów do duchowieństwa. W innych nie umieszczono nawet nowych i ważnych dla księży przepisów i zarządzeń. Te dodatki są cennym, aczkolwiek rzadko wykorzystywanym źródłem dla historyków, ze względu niewielką liczbę zachowanych egzemplarzy oraz brak opisu zawartości, które zmuszają do długotrwałej kwerendy. Publikowany katalog krakowskich rubrycel ma być pomocą w szybkim odszukaniu przydatnych historykowi informacji.

Słowa kluczowe: kalendarze liturgiczne (rubrycele); diecezja krakowska; schematyzmy duchowieństwa; przepisy liturgiczne; katolickie oświecenie

* Ks. Jan Szczepaniak - prof. nauk humanistycznych; Instytut Historii, Uniwersytet Papieski Jana Pawła II w Krakowie

e-mail: jan.szczepaniak@upjp2.edu.pl

https://orcid.org/0000-0001-5365-8146 
Zasadniczą częścią każdego kalendarza liturgicznego były szczegółowe przepisy regulujące sprawowanie liturgii eucharystycznej oraz godzin kanonicznych. Ze względu na skomplikowane zasady konstruowania kalendarza obchodów świątecznych, wspomnień świętych i błogosławionych (mając na uwadze ruchome święta i podział komemoracji na klasy) rubrycela stawała się podstawową i powszechnie wykorzystywaną przez duchownych pomocą do porządku nabożeństw parafialnych, wyboru odpowiednich dla nich formularzy mszalnych oraz związanych z nimi modlitw brewiarzowych. Powszechnie dodawano do nich, zarówno w kalendarzach wydawanych przez władze diecezjalne, jak i władze zakonne, tablice faz Księżyca oraz wykazy wschodu i zachodu Słońca ${ }^{1}$.

Poza kalendarzem liturgicznym obowiązującym we wszystkich kościołach parafialnych diecezji krakowskiej w ciągu 26 lat wydrukowano uzupełnienia do kalendarza liturgicznego obowiązujące w kolegiacie św. Jerzego na Wawelu (1735, 1751, 1753, 1757, 1758, 1760-1768, 1770-1774, 1776, 1778, 1780, 1782, $1783,1785)$, dwa razy w kolegiacie skalbmierskiej $(1757,1758)$ oraz raz dla dekanatów bytomskiego i pszczyńskiego. Uprzywilejowanie w tym względzie kolegiaty św. Jerzego było zrozumiałe, ponieważ rubrycele przygotowywał do druku kanonik tej kolegiaty, posiadający prebendę Wojciechowską, o czym będzie jeszcze mowa. Wydrukowanie dodatku do kalendarza liturgicznego dla dekanatów śląskich to ślad trudnej wówczas do rozstrzygnięcia kościelnej przynależności tych ziem z powodu pruskiej polityki względem dworu wiedeńskiego. W $1797 \mathrm{r}$. władze pruskie, nie chcąc sprowokować Austriaków do odebrania biskupowi wrocławskiemu uprawnień jurysdykcyjnych dla części diecezji leżącej na Śląsku austriackim, pozostawiły biskupowi krakowskiemu władzę nad wyżej wspomnianymi dekanatami (władzę nad dekanatami lelowskim i siewierskim bp Feliks Turski zmuszony był przekazać, zgodnie z konwencją petersburską, biskupowi wrocławskiemu). Sytuacja ta pozostała bez zmian do 1807 r., do czasu utworzenia Księstwa Warszawskiego².

\section{Dodatki liturgiczne do rubrycel}

Ze względu na powszechność korzystania z kalendarza przez księży zaczęto dołączać do rubryceli informacje o nabożeństwach i praktykach obowiązujących w całej diecezji, zarządzenia władz duchownych i świeckich, szczególnie dotyczące zmian przepisów liturgicznych i postnych. Te dodatki są cennym, aczkolwiek rzadko wykorzystywanym źródłem dla historyków badających różne aspekty życia kościelnego i religijnego.

Zasadniczo w każdej zachowanej w krakowskim zbiorze rubryceli można odnaleźć dodatki dotyczące przepisów liturgicznych. W każdym roku redaktorzy umieszczali przypomnienia o obowiązujących przepisach liturgicznych, komentarze do nich, a niekiedy także rozporządzenia wprowadzające nowości.

${ }^{1}$ Ł. Krucki, Katalogi rubrycel i schematyzmów zakonów oraz zgromadzeń zakonnych przechowywanych $w$ księgozbiorze podręcznym Archiwum Archidiecezjalnego w Gnieźnie (1767-2008), „Hereditas Monasteriorum”, 6 (2015) s. 349.

${ }^{2}$ B. Kumor, Ustrój i organizacja Kościoła polskiego w okresie niewoli narodowej (1772-1918), Kraków 1980, s. 182-184. 
Komentarze i przypomnienia dotyczą wielu kwestii. Drukowanie obowiązujących od dawna przepisów niekoniecznie musiało oznaczać, że redagujący kalendarz starał się przypominać te zasady, które duchowni powszechnie naruszali. Różnorodność publikowanych przepisów może jedynie świadczyć o chęci przypominania księżom trudniejszych do zrozumienia i przestrzegania przepisów, bez specjalnego zamysłu dyscyplinowania. Natomiast publikowanie nowych przepisów wyraźnie pokazuje, jakie nowości starano się wprowadzić w diecezji krakowskiej do praktyki życia liturgicznego. Konieczność wydawania tanich, dostępnych dla przeciętnego księdza kalendarzy liturgicznych - i do tego wykorzystywanych tylko raz - wymuszała na redaktorach i wydawcach oszczędność w publikacji dodatkowych treści. $Z$ tego powodu nowości liturgicznych nie było zbyt wiele. W zachowanych XVIII-wiecznych rubrycelach można odnaleźć zaledwie 27 takich dokumentów: $21 \mathrm{z}$ nich dotyczyło przepisów liturgicznych wprowadzanych przez Stolicę Apostolską ( $8 \mathrm{z}$ nich to nowe formularze brewiarzowe i mszalne o błogosławionych i świętych Polakach), a 6 przez rządców diecezji krakowskiej.

Przypomnienia dawnych rozporządzeń oraz podanie do wiadomości nowych decyzji władz kościelnych dotyczyło kwestii podstawowych, ważnych dla każdego duszpasterza. Przypomniano księżom liturgiczne przepisy dotyczące obchodów świątecznych (1778), mszy św. roratniej (1774) oraz zasady celebrowania Eucharystii w kaplicach i oratoriach prywatnych (1753). Podano zmiany w obrzędach liturgicznych: przepisy dotyczące odmawiania modlitwy Anioł Pański (1753) i dekret z 1 lutego 1744 r. Kongregacji Obrzędów w sprawie wprowadzenia formularza oficjum i mszy św. o Najświętszym Grobie Pana Jezusa (1745). To ostanie rozporządzenie ważne było ze względu na szeroko propagowany przez bożogrobców z Miechowa kult Grobu Zbawiciela oraz próbę powoływania przy kościołach parafialnych Bractw Grobu Pańskiego na wzór bractwa miechowskiego. Formularze brewiarzowe i mszalne przygotowane przez miechowitów zatwierdził Benedykt XV na prośbę generała zakonu ks. Jakuba Radlińskiego ${ }^{3}$. Dwa ogłoszone w rubrycelach dokumenty Klemensa XIII dotyczyły diecezji krakowskiej. Dekret z 21 listopada 1759 r. nadawał przywileje ołtarzom w kościołach diecezji krakowskiej, przy których sprawowano msze św. za zmarłych (1761), a brewe z 21 stycznia 1761 r. dotyczyło odpustów na godzinę śmierci dla wszystkich wiernych diecezji krakowskiej, z stosownymi zarządzeniami dla duchowieństwa, podpisanymi przez ordynariusza (1762).

Opublikowano zarządzenia wprowadzające i uzupełnienia do tekstów liturgicznych związane z żywym w Rzeczpospolitej kultem dawnych świętych: św. Barbary (1761), śś. Piotra i Pawła App., św. Szczepana (1776) oraz św. Joachima (1768). W XV wieku Wydział Teologiczny Akademii Krakowskiej wybrał św. Barbarę za swoją patronkę. W drugiej połowie XVIII wieku była patronką 59 kościołów parafialnych. Uznawano ją za patronkę dobrej śmierci, czystości narzeczeńskiej, dobrego życia rodzinnego. Zwracano się do niej w godzinę śmierci, w trakcie pożarów i burz z piorunami. Była opiekunką górników, hutników, ma-

${ }^{3}$ F. Mróz, Sanktuaria i kaplice Bożego Grobu w Polsce, „Peregrinus Cracoviensisi”, 8 (2000) s. 79-114; P. Pękalski, O początku, rozkrzewieniu i upadku Zakonu XX. Kanoników Stróżów św. Grobu Jerozolimskiego, Kraków 1867, s. 36-39. 
rynarzy, rybaków, żołnierzy, artylerzystów, rakietników, kamieniarzy, murarzy, cieśli i więźniów ${ }^{4}$. Kult śś. Piotra i Pawła obecny był w Polsce od czasów przyjęcia chrześcijaństwa przez dwór książęcy. W czasach wczesnopiastowskich św. Piotr, zazwyczaj występujący w towarzystwie św. Pawła, był najczęściej wybierany za patrona budowanych kościołów. Na początku XVI wieku w diecezji krakowskiej 28 kościołów parafialnych miało za patronów obu świętych, a 4 samego Księcia Apostołów. Przed rozbiorami Rzeczpospolitej św. Piotr patronował 212 kościołom parafialnym, filialnym bądź zakonnym, a św. Paweł - 2025. Cześć oddawana św. Szczepanowi ściśle związana była z uroczystością Bożego Narodzenia, bowiem Pierwszy Męczennik od czasów starożytności chrześcijańskiej patronował drugiemu dniowi obchodów świątecznych ${ }^{6}$. Wszelkie więc przepisy liturgiczne dotyczące tego świętego znajdowały powszechne zastosowanie.

Wydrukowano dekrety wpisujące do kalendarza kościelnego nowokanonizowanych: św. Alojzego Gonzagę (1738) - kanonizowanego 31 grudnia 1726 r. wspólnie ze św. Stanisławem Kostką przez Benedykta XIII ${ }^{7}$, oraz św. Józefa Kalasancjusza (1771) i św. Joannę Franciszkę de Chantal (1772) - kanonizowanych 16 lipca 1767 r. przez Klemensa XIII ${ }^{8}$. Kult owych świętych propagowany był przez zakony silnie związane z Krakowem i diecezją krakowską: jezuitami (św. Alojzy Gonzaga), pijarami (św. Józef Kalasancjusz) i wizytkami (św. Joanna Franciszka de Chantal). Od 1621 r. obchodzono w Rzeczpospolitej uroczyście wspomnienie św. Alojzego, patrona młodzieży, a po 1637 r. wraz z św. Stanisławem Kostką uznawano go za obrońcę Smoleńska. Jego osobę popularyzowały dramaty wystawiane w szkolnych teatrach kolegiów jezuickich oraz szeroko rozpropagowane nabożeństwo sześcioniedzielne ${ }^{9}$. Pijarzy zaś propagowali kult swojego założyciela w prowadzonych przez siebie elitarnych kolegiach kształcących młodzież. W diecezji krakowskiej działały ich trzy wielkie kolegia ze szkołami w Podolińcu (od 1642), Radomiu (od 1685) i Łukowie (od 1696) oraz dwie rezydencje bez szkół w Krakowie (od 1674) i Nowym Sączu (od 1733). Warto dodać, że w Krakowie - ze względu na stanowisko Akademii Krakowskiej - nie było

${ }^{4}$ Z. Kupisiński, Kult świętej Barbary w polskiej religijności ludowej, „Roczniki Teologii Fundamentalnej i Religiologii”, 4(59) (2012) s. 244-247; W. Rozynkowski, Św. Barbara i Barbarkawokót początków kultu świętej męczennicy, w: Św. Barbara i Barbarka, red. W. Rozynkowski, W. Miszewski, Toruń 2005, s. 14-15; S. Litak, Atlas Kościoła łacińskiego w Rzeczypospolitej Obojga Narodów w XVIII wieku, Lublin 2006, s. 428.

${ }^{5}$ Litak, Atlas Kościoła łacińskiego, s. 434; M. Starnawska, Kult św. Piotra w Polsce średniowiecznej na tle europejskim, „Ecclesia. Studia z Dziejów Wielkopolski”, 6 (2011), s. 29-32.

${ }^{6}$ W. Kamczyk, Kult świętego Szczepana w duszpasterstwie biskupa Augustyna z Hippony, „Śląskie Studia Historyczno-Teologiczne", 49 (2016) z. 2, s. 312-313.

${ }^{7}$ W.S. Artuñeda, Celebraciones por las canonizaciones de jesuitas en el Colegio de Málaga en la Edad Moderna, „Revista de Historia Moderna: Anales de la Universidad de Alicante”, (2003) nr 21, s. 149.

${ }^{8}$ S.G. Guerri, San José de Calasanz, Madrid 1985, s. 180; S. Rouez, Les cérémonies en l'honneur de la béatification et de la canonisation de Jeanne de Chantal. Entre dévotion privée des visitandines et dévotion publique, „Revue Mabillon”, 13(74) (2002) s. 265.

${ }^{9}$ Alojzy Gonzaga, w: Encyklopedia wiedzy o jezuitach na ziemiach Polski i Litwy, oprac. L. Grzebień SJ przy współpracy zespołu jezuitów, Kraków 2004, s. 8. 
szkoły pijarskiej, jednak prowadzili oni studium teologii spekulatywnej, w którym zdobywali wykształcenie nauczyciele szkół pijarskich ${ }^{10}$. W diecezji krakowskiej istniały przed rozbiorami dwa z czterech polskich klasztorów wizytek, w Krakowie (od 1681) i Lublinie (od 1723). Pierwszy z nich fundował ordynariusz krakowski bp Jan Małachowski. Przy obu klasztorach siostry prowadziły elitarną szkołę dla dziewcząt $\mathrm{z}$ arystokratycznych rodzin ${ }^{11}$.

W rubryceli znalazły się również dokumenty związane z kultem polskich świętych i błogosławionych, związanych z diecezją krakowską. Otwiera je dekret Kongregacji Obrzędów z 5 września 1739 r. ogłaszającej bł. Jana z Dukli patronem Polski i Litwy (1751). Jego kult został potwierdzony 23 stycznia $1733 \mathrm{r}$ przez Klemensa XII ${ }^{12}$. W kalendarzu ukazały się także teksty brewiarzowe o bł. Wincentym Kadłubku wraz ze stosownymi zarządzeniami (1766). Opublikowano je po potwierdzeniu przez Kongregację Obrzędów 11 lutego 1764 r. jego kultu, na podstawie którego 18 lutego 1764 r. Klemensa XIII ogłosił dekret beatyfikacyjny, a 9 czerwca 1764 r. zezwolił na odprawienie mszy św. w diecezji krakowskiej i zakonie cystersów ${ }^{13}$. Kolejnym dokumentem związanym z kultem polskich świętych było opublikowanie tekstów brewiarzowych na święto bł. Szymona z Lipnicy (1780). Dotyczyło to trwającego procesu kanonizacyjnego ${ }^{14}$. W krakowskim kalendarzu liturgicznym wydrukowano także pięć dokumentów związanych z kultem św. Jana Kantego, beatyfikowanego 27 września 1760 r. przez Innocentego XI, a kanonizowanego 16 lipca 1767 r. przez Klemensa XIII ${ }^{15}$ : dekrety Kongregacji Obrzędów z 1737 r. i 1738 r. dotyczące święta błogosławionego (1738), dekret ustanawiający św. Jana Kantego patronem Polski (1769), dekrety o wpisaniu do kalendarza liturgicznego św. Jana Kantego (1771) oraz zarządzenia dotyczące kultu świętego (1772) i sprawowania oficjum oraz mszy św. cichej o św. Janie Kantym (1783).

${ }^{10} \mathrm{H}$. Bogdziewicz, Działalność literacka polskiego środowiska pijarskiego w dobie oświecenia, Kraków 2005, s. 16-18; J. Długosz, Ślazacy uczniami szkoły pijarskiej w Podolińcu na Spiszu, „Śląski Kwartalnik Historyczny. Sobótka”, 30 (1975) nr 2, s. 269-270; M. Gotkiewicz, Trzy wieki kolegium podolinieckiego (1642-1942), „Nasza Przeszłość” (dalej: NP), 15 (1962) s. 85-88; A. Pitala, Kolegium pijarów w Krakowie (szkic historyczny), NP, 15 (1962) s. 70; S. Postek, Dzieje szkoły pijarskiej w Eukowie 1701-1833, „Analecta: studia i materiały z dziejów nauki”, 5 (1996) nr 2 (10), s. 142-144.

${ }^{11} \mathrm{Cz}$. Hadamik, Kościół Wizytek $w$ Lublinie $w$ świetle ratowniczych badań archeologicznych w 2010 roku, „Wiadomości Konserwatorskie”, 30 (2011) s. 60; F.S. Ignaszewska, Historia fundacji klasztoru SS. Nawiedzenia NMP (Wizytek) w Krakowie (1681-1699), NP, 58 (1983) s. 5-93.

12 J. Bar, Polskie procesy kanonizacyjne i beatyfikacyjne, „Ruch Biblijny i Liturgiczny”, 11 (1958) s. 431; M. Kuczkowski, Św. Jan z Dukli w świetle polskich czasopism tercjarskich (19181939), „Roczniki Teologiczne”, 61 (2014) z. 4, s. 161; A.K. Sitnik, Święty Jan z Dukli, „Folia Historica Cracoviensia”, 15-16 (2009-2010) s. 111.

${ }^{13}$ J. Bar, Polskie zakony, „Prawo Kanoniczne”, 4 (1961) nr 1-4, s. 431-432; J.J. Janicki, Błogosławiony Wincenty Kadlubek - nauczyciel miłości Boga i Ojczyzny, w świetle tekstów liturgicznych i nauczania Kościoła, „Kieleckie Studia Teologiczne”, 9 (2010) s. 36.

${ }^{14}$ Bar, Polskie zakony, s. 430.

${ }^{15}$ Tamże, s. 430, 435-436. 
W rubrycelach na lata 1769-1771 opublikowano słownik pojęć biblijnych, teologicznych i liturgicznych używanych w brewiarzu i mszale rzymskim.

\section{Dokumenty kościelne i listy pasterskie}

Kolejną grupą dokumentów publikowanych w XVIII wieku w kalendarzach liturgicznych diecezji krakowskiej były rzymskie dokumenty kościelne oraz listy pasterskie i zarządzenia rządców diecezji krakowskiej dotyczące spraw duszpasterskich lub dyscypliny kościelnej. W zachowanych rubrycelach można znaleźć 15 dokumentów o takim charakterze, w tym 3 przygotowane przez Stolicę Apostolską oraz 12 wydanych przez ordynariuszy i wikariuszy generalnych diecezji krakowskiej.

Tak jak w przypadku rozporządzeń rzymskich dotyczących spraw liturgicznych, opublikowane w krakowskich rubrycelach dokumenty duszpasterskie i porządkujące praktykę życia kościelnego przynajmniej w dwóch przypadkach związane były z kwestiami, którymi interesowało się polskie duchowieństwo. Pierwszy dokument - konstytucja Benedykta XIV z 1747 r. dotycząca chrztu Żydów (1761) - przypominał zasady udzielania chrztu Żydom. Zapewne wydrukowano go ze względu na widoczne w połowie tegoż wieku zjawisko konwersji Żydów -mieszczan na chrześcijaństwo oraz szerzącą się w Rzeczpospolitej kontrowersyjną żydowską sektę religijną, tzw. frankistów, zwolenników Jakuba Józefa Franka (w 1759 r. przyjął pozorny chrzest, za co rok później został aresztowany i osadzony przymusowo w klasztorze) ${ }^{16}$. Drugi dokument to dekrety dotyczące erygowania Bractwa Najświętszego Serca Pana Jezusa (1767). W połowie XVIII wieku kult Najświętszego Serca Pana Jezusa, związany z objawieniami św. Małgorzaty Marii Alacuque, znalazł w Rzeczpospolitej licznych zwolenników. Na prośbę biskupów polskich w 1765 r. Klemens XIII ustanowił uroczystość Najświętszego Serca Pana Jezusa (dekret początkowo obowiązywał w Polsce i na Litwie oraz w Bractwie Serca Jezusowego w Rzymie). Pierwsze Bractwo Serca Pana Jezusa w Polsce założono w 1705 r. w Warszawie, kolejne w 1718 r. Krakowie, przy kościele wizytek ${ }^{17}$. Trzeci dokument to dekret wpisujący kolejne pozycje wydawnicze do spisu ksiąg zakazanych (1772).

W rubrycelach znalazły się również dwa listy pasterskie ordynariuszy (bp. Andrzeja Załuskiego i bp. Kajetana Ignacego Sołtyka) oraz dziewięć zarządzeń bp. K.I. Sołtyka dotyczących spraw liturgicznych i dyscyplinarnych, przygotowanych przez biskupów pomocniczych: Franciszka Podkańskiego i Józefa Olechowskiego.

${ }^{16}$ A. Kaźmierczyk, Rodziłem się Żydem... Konwersje Żydów w Rzeczypospolitej XVII-XVIII wieku, Kraków 2015, s. 21-24; M. Soboń, Od wspólnoty charyzmatycznej do grupy interesów: przypadek frankizmu, „Czasy Nowożytne”, 16 (2004) s. 79-124.

${ }^{17}$ L. Poleszak, Zarys historii kultu Najświętszego Serca Pana Jezusa na przestrzeni ostatnich stuleci, w: Zawierzyć Sercu Jezusa, red. W. Kubik, Kraków 2011, s. 31-51; I. Słoma, 250 lat liturgicznego kultu Serca Jezusowego w Polsce - Memoriat biskupów polskich z 1765 roku, „Roczniki Teologiczne", 62 (2015) z. 8, s. 145-158. 
Wydrukowany dwukrotnie list pasterski bp. A. Załuskiego, skierowany do duchowieństwa, dotyczył uchybień w obowiązku rezydencji oraz nieprawidłowości w dzierżawie dóbr kościelnych, m.in. ze względu na brak zgody władzy duchownej na zawarcie umowy $(1757,1758)$. Natomiast list pasterski bp. K.I. Sołtyka z 6 lipca 1775 r. podnosił temat redukcji świąt obowiązkowych. Podpisane przez tegoż w 1765 r. zarządzenie przypominało o możliwości, a także podawało zasady udzielania odpustów in articulo mortis. Wydana przez niego rok później instrukcja dotyczyła zasad prowadzenia przez plebanów kancelarii parafialnej oraz obowiązku składania przez dziekanów sprawozdań rocznych. Biskup pomocniczy F. Potkański podpisał 12 marca 1761 r. i nakazał wydrukować w rubryceli komunikat do duchowieństwa i wiernych w sprawie zasad organizacji misteriów Wielkiego Tygodnia. Również jego autorstwa były: zarządzenie omawiające zasady wystawienia Najświętszego Sakramentu, opublikowane w 1767 r., oraz podające do publicznej wiadomości porządek uroczystości po kanonizacji św. Jana Kantego, wydrukowane w rubryceli na $1769 \mathrm{r}$. W trzech rocznikach rubryceli znalazły się ,przestrogi” i „zalecenia” wspomnianego wyżej ordynariusza diecezji krakowskiej, zredagowane przez biskupa pomocniczego diecezji krakowskiej J. Olechowskiego. W 1776 r. dotyczyło ono zniesienia w obu częściach diecezji krakowskiej zwyczajów biczowania się w czasie nabożeństw wielkopostnych (,kapnicy”) oraz wprowadzenia w diecezji przepisów postnych obowiązujących w Kościele powszechnym (pozwolenie na używanie w piątki potraw „mlecznych czyli maślanych”). Rok później w „zaleceniach” zwrócono uwagę duchowieństwu, że istnieje obowiązek podporządkowania się przepisom kościelnym znoszącym niektóre święta, a także zakazowi traktowania petyty jako zobowiązania finansowego parafian, a nie przywileju. Ostrzeżono także rządców parafii przez Stanisławem Morawskim, fałszerzem dokumentów kościelnych. W 1779 r. w ,zaleceniach" zezwolono kwestarzom zakonnym na przeprowadzanie zbiórki we dworach, podtrzymując wcześniejszy zakaz kwesty wśród chłopów. Zakazano również zbierania darów w naturze w czasie wypominek oraz wykorzystania kun znajdujących się przy kościołach do wymierzania kar. Zwrócono również uwagę na konieczności przestrzegania wymogów sanitarnych przy grzebaniu zmarłych, zasad poboru dziesięciny oraz obowiązku płacenia subsidium charitativum.

Przegląd publikowanych listów pasterskich i zarządzeń skierowanych do duchownych, a niekiedy również do wiernych diecezji krakowskiej, pokazuje, że rubrycele wykorzystywano jako narzędzie wprowadzania oświeceniowych zasad w kwestiach pobożności i dyscypliny kościelnej ${ }^{18}$.

\section{Spisy zmarlych księży i katalogi kanoników katedralnych}

Wspomniano wyżej, że od rubryceli przygotowanej na $1751 \mathrm{r}$. wydrukowano po raz pierwszy spis zmarłych w 1749 r. księży. Odtąd w każdym kalendarzu zamieszczano taki spis. Coroczne katalogi zmarłych nie są jednak pełne, o czym świadczą informacje o zgonie księży pozyskane z innych źródeł. W rubrycelach, poza imieniem i nazwiskiem zmarłego, odnotowywano funkcję, jaką pełnił

\footnotetext{
${ }^{18}$ J. Kracik, Post po staropolsku, NP, 75 (1991) s. 83-88.
} 
W chwili śmierci. Dzienna data zgonów pojawiała się w większości podanych przypadków od 1754 r. Dzięki praktyce publikowania spisu zmarłych znana jest przynajmniej roczna data śmierci 2206 duchownych zmarłych w latach 1749$1810^{19}$.

Pierwsze katalogi duchowieństwa dołączono do rubryceli na 1753 r. Był to katalog prałatów i kanoników krakowskiej kapituły katedralnej. Pełny spis parafii i duchowieństwa wydrukowano dopiero w $1811 \mathrm{r}$. Nie był to jednak pierwszy schematyzm sporządzony w krakowskim konsystorzu. Pierwszy znany rękopiśmienny katalog parafii i duchowieństwa sporządzono na przełomie 1751 i $1752 \mathrm{r}^{20}{ }^{20}$ Kolejne powstały w latach 1783-1784 i 1790. Dokumenty te sformułowano $\mathrm{w}$ trakcie prac prowadzonych przez władze kościelne i państwowe nad sporządzeniem opisu geograficznego i statystycznego Rzeczpospolitej, w czasie zmian granic diecezji ${ }^{21}$. Integralnie $\mathrm{z}$ nimi związana jest księga uposażeń przygotowana w $1787 \mathrm{r}^{22}$

Warto zauważyć, omawiając zawartość XVIII-wiecznych rubrycel, że z tego typu publikacji wyodrębniły się nie tylko schematyzmy diecezjalne jako samoistne publikacje, ale i diecezjalne pisma urzędowe. To w nich znalazły miejsce zarządzenia władz kościelnych, dokumenty Stolicy Apostolskiej, nowe przepisy liturgiczne oraz listy pasterskie początkowo publikowane w kalendarzach. Pierwsze tego typu pisma zaczęto wydawać w Galicji, we Lwowie (1844) ${ }^{23}$, Tarnowie $(1851)^{24}$ i Krakowie $(1863)^{25}$. Następnie w diecezjach pod zaborami: pruskim ${ }^{26}$ i znacznie później - rosyjskim ${ }^{27}$.

W niektórych rocznikach rubryceli wydawcy starali się dołączyć do każdego egzemplarza kilka wolnych kart przeznaczonych na notatki. W 29 przypadkach każda składka kalendarza, poczynając od drugiej, została włożona w czystą składkę folio $(1751,1757-1760,1762-1764,1766,1771-1774,1776,1788,1791,1792$,

${ }^{19}$ J. Szczepaniak, Duchowieństwo diecezji krakowskiej w XVIII wieku. Studium prozopograficzne, Kraków 2010, s. 294-295; tenże, Nekrologium. Księża diecezji krakowskiej zmarli w latach 1749-1810, Kraków 2010.

${ }^{20}$ J. Szczepaniak, Najstarsze spisy duchowieństwa diecezji krakowskiej, „Folia Historica Cracoviensia", 11 (2005) s. 157-359.

${ }^{21}$ Kościót i społeczeństwo Małopolski w II połowie XVIII w. Materiaty źródtowe, t. 2: Duchowieństwo diecezji krakowskiej, oprac. J. Szczepaniak, Lublin 2010.

${ }^{22}$ Kościót i społeczeństwo Małopolski w II połowie XVIII w. Materiaty źródłowe, t. 1: Ludność i organizacja diecezji krakowskiej, oprac. B. Szady, Lublin 2010.

${ }^{23}$ „Verordnungen des Lemberger lat[einischen] Metropolitan Konsistorium Militär-Jahr”, 1 (1844). Od 1854 r. zmiana nazwy: „Currendae Consistorii Metropolit[ani] r[itus] 1[atini] Leopol[iensis] in negotii ecclesiasticis ex anno[...]".

${ }^{24}$ „Currenda. De Notificationibus. Konsystorz Biskupi w Tarnowie”, 1 (1851).

${ }^{25}$ „Ex Consistorio Generali Dioecesis Cracoviensis Notificationes ad uniwersum venerabilem clerum tam saecularem quam regularem partis Dioecesos Cracoviensis in civilibus imperio Caesareo Austriaco subjectae", 1 (1863).

${ }^{26}$ „Amtliches Kirchenblatt für die Diözese Culm. Herausgegeben und verlegt von den Bischöflichen General-Vikariat-Atm von Culm", 1 (1858).

${ }^{27}$ „Kronika Diecezji Kujawsko-Kaliskiej”, 1 (1906); „Miesięcznik Pasterski Płocki”, 1 (1907). 
1811), a w 11 dołączono kilka pustych kart, od 2 do 9 (1761, 1767-1770, 1777, 1780, 1783, 1798, 1800, 1801).

\section{Notatki właścicieli rubrycel}

W 21 egzemplarzach rubrycel znajdują się notatki i marginalia właścicieli. Zazwyczaj dotyczą one spraw gospodarczych i finansowych oraz liturgii i obowiązków mszalnych. W czterech przypadkach są to notatki z lektury duchowej, a w trzech - spraw personalnych, w tym metrykalnych.

Notki odnoszące się do spraw finansowych to uwagi gospodarcze, szczególnie dotyczące powinności gospodarczych $(1758,1763,1764,1774,1791)$, spisy wydatków $(1769,1770,1771,1774,1776,1783,1788,1799,1800)$, spis otrzymanych dziesięcin (1788), informacje o pożyczce (1792) i opis pogody zapisywany w kontekście rytmu prac gospodarczych (1791).

Zapiski dotyczące liturgii i intencji mszalnych zasadniczo odnoszą się do przyjętych i odprawionych intencji mszalnych $(1758,1760,1762,1764,1766$, $1767,1769,1771,1777,1778,1783,1791,1792,1796)$, niekiedy z notkami o wielkości złożonej ofiary (1762). W jednym przypadku właściciel ręcznie dopisał uzupełnienia do kalendarza liturgicznego dotyczącego kościoła Mariackiego w Krakowie na miesiące wakacyjne (1792).

Notki związane z życiem duchowym są cytatami z lektury Pisma Świętego i ojców Kościoła oraz książek ascetycznych $(1751,1758,1768)$. W jednym przypadku właściciel kalendarza przepisał fragment Elementarzyka ćwiczenia duchownego dominikanina Mikołaja z Mościsk (1767).

Napisanych przez właścicieli notatek dotyczących spraw personalnych jest niewiele. W katalogu na 1774 r. proboszcz z Przytkowic odnotował informacje o chrztach i ślubach. W rubryceli na lata 1777 i 1792 znalazły się krótkie spisy zmarłych. W tym ostatnim kalendarzu właściciel zapisał skład krakowskiej Rady Miejskiej. Do tej kategorii zapisków należy również informacja o śmierci i pogrzebie bp. F. Turskiego z dopiskiem poczynionym ołówkiem: „Niech mu P. Bóg nie pamięta krzywd które mi poczynił" (1800).

Do żadnej z tych kategorii nie należy zanotowany przez właściciela w rubryceli na 1776 r. przepis leku na „kurcz, paraliż, reumatyzm, podagrę”.

Wiek XVIII dał do ręki plebanom, nawet parafii odległych od większych miast, podstawowe narzędzie pozwalające zachować przepisy liturgiczne dotyczące sprawowania mszy św. i odmawiania liturgii godzin. Bez żadnych trudności biskupi, współpracujący z nim kanonicy oraz podlegli ordynariuszowi urzędnicy konsystorscy byli wstanie przygotować do druku, wydać wystarczającą liczbę egzemplarzy i zorganizować coroczną dystrybucję kalendarzy liturgicznych do wszystkich parafii rozległej diecezji. Nabycie rubryceli nie przekraczało także możliwości finansowych biedniejszych plebanów. Zakup, posiadanie i używanie tego typu druków stały się regułą, w związku z czym można było je wykorzystać jako dodatkowy sposób przekazywania duchownym ważnych informacji i zarządzeń. Opisane rubrycele drukowane dla duchowieństwa diecezji krakowskiej pozwalają zapoznać się w procesem formowania kalendarzy liturgicznych i schematyzmów diecezjalnych. Są także źródłem wielu informacji o życiu liturgicznym 
diecezji, życiu codziennym duchowieństwa, a w późniejszych latach także informacji przydatnych do tworzenia biogramów księży.

\section{KATALOG RUBRYCEL Z LAT 1735-1811}

Poniższy katalog zawiera opis bibliograficzny 50 tomików rubrycel diecezji krakowskiej za lata 1835-1811. Składa się on z następujących elementów: (1) tytuł druku; (2) imię i nazwisko osoby odpowiedzialnej za jego redakcję; (3) miejsce i datę wydania; (4) wydawcę, nazwisko typografa, nazwisko właściciela drukarni bądź nazwę drukarni; (5) opis strony tytułowej; (6) opis zawartości tomu, (7) opis oprawy oraz (8) sygnaturę w katalogu archiwalnym.

\section{1.}

Rubricella dioecesis Cracoviensis [...] ad annum Domini MDCCXXXV [...] conscripta [...]. Jonnes Gorecki, can[onicus]. s. Georgii, vicedec[anus] e[cclesiae] c[athedralis] C[racoviensis], [Cracoviae 1734]. Na ostatniej stronie: „Cracoviae. Typis Jacobi Matyszkiewicz, S.R.M, Celsissimi Illustrissimi et Reverendissimi Episcopi Cracov. Ducis Severiae Ordinarii typogr." $8^{\circ}$ nlb.

Treść: Herb kard. Jana Lipskiego (Grabie) w środku karty tytułowej odciśnięty czarną farbą. Po obu stronach drzeworytu czerwone inicjały tytulatury. Pod nim wiersz na cześć ordynariusza krakowskiego. Główny zrąb rubryceli: „Revolutiones annuae, festa mobilia"; kalendarz liturgiczny na każdy dzień roku; komentarze do rubryk dotyczące odmawiania oficjum w dni patronów Królestwa Szwecji; „Tabula ortus et occasus solis...”. Są czyste składki przeznaczone do notatek i zapisków księży.

Oprawa: nowa, płócienna.

Sygn. 1

\section{2.}

Rubricella dioecesis Cracoviensis [...] ad annum Domini MDCCXXXVIII [...] conscripta [...]. Jacobs Kapuściński, canon[onicus] s. Georg[orii], vicedecanus] e[cclesiae] c[athedralis] C[racoviensis], [Cracoviae 1737]. Na ostatniej stronie: „Cracoviae. Typis viduae et haeredum Jacobi Matyaszkiewicz, S.R.M, et Celsissimi Illustrissimi et Reverendissimi Episcopi Cracoviensis, Ducis Severiae, Ordinarii typographi". $8^{\circ}$ nlb.

Treść: Na środku strony tytułowej czarny drzeworyt herbu kard. Jana Lipskiego, z obu stron otoczony czerwonymi inicjałami tytulatury. Pond nim wiersz na cześć ordynariusza krakowskiego. Główny zrąb rubryceli: „Revolutiones annuae, festa mobilia; kalendarz liturgiczny na każdy dzień roku; komentarze dotyczące odmawiania oficjum w dni patronalne Królestwa Szwedzkiego; dekrety Kongregacji Obrzędów z 1737 r. i 1738 r. dotyczące święta bł. Jana Kantego i św. Alojzego Gonzagi; „Tabula ortus et occasus Solis...”. Na ostatniej stronie odciśnięte dwa dość przypadkowo wybrane drzeworyty: orzeł bez korony $\mathrm{z}$ szarfami w dziobie, stojący na rogu obfitości oraz ornament z południowych owoców i roślin.

Oprawa: współczesna, papierowa, jednostronnie zielona z tłoczonymi ślepymi wzorami roślinnymi.

Sygn. 2 
3.

Rubricella dioecesis Cracoviensis [...] annum Domini MDCCXLV [...] conscripta [...]. Adalbertus Małocki, c[anonisus] s. Georg[orii], vicedec[anus] e[cclesiae] c[athedralis] C[racoviensis], [Cracoviae 1744]. Na ostatniej stronie: „Cracoviae. Typis Dominici Siarkowski, S.R.M et Eminentissimi, Reverendissimi Domini Cardinalis Episcopi Cracoviensi, Ducis Severiae Ordinarii typogr. et bibliop". $8^{\circ}$ nlb.

Treść: Herb kard. Jana Lipskiego w środku karty tytułowej. Czerwoną farbą wydrukowano tarczę herbową oraz wkomponowane w nią insygnia biskupie, książęce i kardynalskie, czarną - herb. Po obu stronach drzeworytu czerwone inicjały tytulatury. Pod nim wiersz na cześć ordynariusza krakowskiego. Główny zrąb rubryceli: „Revolutiones annuae, festa mobilia"; kalendarz liturgiczny na każdy dzień roku; komentarze do rubryk; dekret z 1 lutego 1744 r. Kongregacji Obrzędów w sprawie wprowadzenia formularza oficjum i mszy św. o Najświętszym Grobie Pana Jezusa; „Tabula ortus et occasus solis...”. Każda składka kalendarza, poczynając od drugiej, została włożona w czystą składkę folio, przeznaczoną do zapisywania notatek. Właściciel kalendarza całkowicie wypełnił je notatkami (przepisy na lekarstwa, notatki z lektury Pisma Świętego i ojców Kościoła).

Oprawa: nowa, płócienna.

Sygn. 3

\section{4.}

[Rubricella dioecesis Cracoviensis [...] ad annum Domini MDCCL [...] conscripta [...], [Cracoviae 1749.] $8^{\circ} \mathrm{nlb}$.

Uwagi: brak karty tytułowej; brak ostatnich stron.

Treść: W zachowanej części - kalendarz liturgiczny na każdy dzień roku; komentarze do rubryk; komentarze do odmawiania oficjum w dni patronalne Królestwa Szwecji. W kalendarzu liturgicznym pod koniec lutego znajduje się pusta karta, zapełniona zapiskami gospodarczymi i powinnościami płatniczymi.

Oprawa: nowa, płócienna.

Sygn. 4

\section{5.}

Rubricella dioecesis Cracoviensis [...] ad annum Domini MDCCLI [...] conscripta [...]. Adalbertus Małocki, c[anonicus] s. Georg[orii], viced[ecanus] e[cclesiae] c[athedralis] C[racovienis], [Cracoviae 1750]. Na ostatniej stronie: ,Reperitur doc directorium in Palatino Episcopali, sumptu Josephi Hayek, Celsissimi Illustrissimi et Reverendissimi Domini Episcopi Cracoviensis, Ducis Severiae, ordinarii Bibliopolae privilegiati”. $8^{\circ} \mathrm{nlb}$.

Treść: Herb bp. Andrzeja Załuskiego (Junosza) w środku karty tytułowej wydrukowany czarną farbą. Po obu stronach drzeworytu czerwone inicjały tytulatury. Pod nim wiersz na cześć ordynariusza krakowskiego. Główny zrąb rubryceli: „Revolutiones annuae, festa mobilia"; kalendarz liturgiczny na każdy dzień roku; uzupełnienia do kalendarza liturgicznego obowiązujące w kolegiacie św. Jerzego na Wawelu; komentarze do rubryk; dekret Kongregacji Obrzędów z 5 września 1739 r. w sprawie czci bł. Jana z Dukli; ,Tabula ortus et occasus solis...”. Na ostatniej stronie pojawia się zaczątek schematyzmu: elenchus duchowieństwa diecezjalnego zmarłego w 1749 r. Każda składka kalendarza, poczynając od drugiej, została włożona w czystą składkę folio, przeznaczoną do zapisywania notatek. 
Karty te są całkowicie zapisane notatkami, zasadniczo w j. łacińskim (cytaty z lektury Pisma Świętego, ojców Kościoła i książek ascetycznych).

Oprawa: nowa, płócienna.

Sygn. 5

6.

Rubricella dioecesis Cracoviensis [...] ad annum Domini MDCCLIII [...] conscripta [...]. Adalbertus Małocki, c[anonicus] s. Georg[orii], viced[ecanus] e[cclesiae] c[athedralis] C[racoviensis], [Cracoviae 1752]. Na ostatniej stronie: „Hoc directorium ex Officio Generali Cracovinsi via cursoria transmittitur. Cracoviae. Typis in Palatio Episcopali per Adamum Klein typographum Cracoviensem”. $8^{\circ}$ nlb.

Treść: Herb bp. Andrzeja Załuskiego (Junosza) w środku karty tytułowej wydrukowany czarną farbą. Po obu stronach drzeworytu czerwone inicjały tytulatury. Pod nim wiersz na cześć ordynariusza krakowskiego. Główny zrąb rubryceli: „Revolutiones annuae, festa mobilia"; kalendarz liturgiczny na każdy dzień roku; uzupełnienia do kalendarza liturgicznego obowiązujące w kolegiacie św. Jerzego na Wawelu; komentarze do rubryk; zmiany w obrzędach i przepisy dotyczące odmawiania modlitwy Anioł Pański; Dekret Klemensa XI z 15 grudnia 1703 r. w sprawie celebrowania mszy św. w oratoriach prywatnych; „,Tabula ortus et occasus solis...". Przed wspomnianym dekretem Klemensa XI oraz tabelami astronomicznymi umieszczono katalog prałatów i kanoników kapituły katedralnej oraz elenchus duchowieństwa zmarłego w $1751 \mathrm{r}$.

Oprawa: nowa, płócienna.

Sygn. 6

7.

Rubricella dioecesis Cracoviensis [...] ad annum Domini MDCCLVII [...] conscripta [...]. Joannes Cantius Jurdziński, c[anonicus] s. Georgorii, vice-dec[anus] e[cclesiae] c[athedralis] C[racoviensis], [Cracoviae 1756]. Na ostatniej stronie zasadniczej części kalendarza: „Hoc directorium ex Officio Generali Cracoviensi via cursoria transmittitur" [...] Cracoviae, typis in Palatio episcopali Dominico Rofenmüller, factore suae Celsitudinis". $8^{\circ} \mathrm{nlb}$.

Treść: Herb bp. Andrzeja Załuskiego (Junosza) w środku karty tytułowej wydrukowany czarna farbą. Po obu stronach drzeworytu czerwone inicjały tytulatury. Pod nim wiersz na cześć ordynariusza krakowskiego. Główny zrąb rubryceli: „Revolutiones annuae, festa mobilia"; kalendarz liturgiczny na każdy dzień roku; uzupełnienia do kalendarza liturgicznego obowiązujące w kolegiacie św. Jerzego na Wawelu oraz kolegiacie skalbmierskiej; przypomnienia przepisów liturgicznych, komentarze do rubryk i zmiany liturgiczne; katalog prałatów i kanoników katedry wawelskiej opatrzony datą 1757; spis zmarłych w 1755 i 1756 r. księży diecezji krakowskiej; „Tabula ortus et occasus solis...”; list pasterski bp. Andrzeja Załuskiego do duchowieństwa w sprawie uchybień w obowiązku rezydencji oraz dzierżawienia dóbr kościelnych bez zgody władzy duchownej. Każda składka kalendarza, poczynając od drugiej, została włożona w czystą składkę folio, przeznaczoną do zapisywania notatek. Pozostały one niezapisane.

Oprawa: współczesna, papierowa, jednostronnie różowa.

Sygn. 7 
8.

Rubricella dioecesis Cracoviensis [...] ad annum Domini MDCCLVIII [...] conscripta [...]. Joannes Cantius Jurdziński, c[anonicus] s. Georgorii, vice-dec[anus] $\mathrm{e}$ [cclesiae] c[athedralis] C[racoviensis], [Cracoviae 1757]. Na ostatniej stronie kalendarza: „Hoc directorium ex Officio Generali Cracoviensi via cursoria transmittitur" [...] Cracoviae, in typographia episcopali Josepho Hajek, administratore suae Celsitudinis". $8^{\circ}$ nlb.

Treść: Herb bp. Andrzeja Załuskiego (Junosza) w środku karty tytułowej wydrukowany czarną farbą. Po obu stronach drzeworytu czerwone inicjały tytulatury. Pod nim wiersz na cześć ordynariusza krakowskiego. Główny zrąb rubryceli: „Revolutiones annuae, festa mobilia"; kalendarz liturgiczny na każdy dzień roku; uzupełnienia do kalendarza liturgicznego obowiązujące w kolegiacie św. Jerzego na Wawelu oraz kolegiacie skalbmierskiej; przypomnienia przepisów liturgicznych, komentarze do rubryk i zmiany liturgiczne; katalog prałatów i kanoników katedry wawelskiej opatrzony datą 1758; spis zmarłych w 1756 i 1757 r. księży diecezji krakowskiej; „Tabula ortus et occasus solis...”; list pasterski bp. Andrzeja Załuskiego do duchowieństwa w sprawie uchybień w obowiązku rezydencji oraz dzierżawienia dóbr kościelnych bez zgody władzy duchownej. Każda składka kalendarza, poczynając od drugiej, została włożona w czystą składkę folio, przeznaczoną do zapisywania notatek. Nieznany właściciel umieścił tam zapiski w j. polskim i łacińskim dotyczące intencji mszalnych, uwagi gospodarcze oraz sentencje z przeczytanych książek. Oprawa: nowa, płócienna.

Sygn. 8

\section{9.}

Ordo officii divini pro dioecesi Cracoviensi [...] ad annum Domini MDCCLIX [...] conscriptus [...]. Joannes Cantius Jurdziński, c[anonicus] s. Georgorii, vicedec[anus] e[cclesiae] c[athedralis] C[racoviensis], [Cracoviae 1758]. $8^{\circ} \mathrm{nlb}$.

Uwagi: brak ostatniej składki.

Treść: Herb bp. Andrzeja Załuskiego (Junosza) w środku karty tytułowej wydrukowany czarną farbą. Po obu stronach drzeworytu czarne inicjały tytulatury. Pod nim wiersz na cześć ordynariusza krakowskiego. Główny zrąb rubryceli: „Revolutiones annuae, festa mobilia"; kalendarz liturgiczny na każdy dzień roku. Brak dalszych części, ze względu na niezachowaną ostatnią część kalendarza. Każda składka kalendarza, poczynając od drugiej, została włożona w czystą składkę folio, przeznaczoną do zapisywania notatek. Pozostały one niezapisane. Na wewnętrznej stronie okładki wpis własnościowy Cyryla Kossa, zakonnika krakowskiego klasztoru Kanoników od Pokuty (marków) z 1 stycznia 1759 r.

Oprawa: współczesna, papierowa, jednostronnie amarantowa.

Sygn. 9

10.

Rubricella dioecesis Cracoviensis [...] ad annum Domini MDCCLX [...] conscripta [...]. [Joannes Cantius Jurdziński canonicus s. Georgorii, vicedecanus ecclesiae cathedralis Cracoviensis, Cracoviae 1759]. Na ostatniej stronie kalendarza: „Cracoviae. Typis Sebastiani Fabiani Hebanowski S.R.M. typogr. bibliop. Cracov. et Varsavien”. $8^{\circ}$ nlb. 
Treść: Herb bp. Kajetana Sołtyka (Sołtyk) w środku karty tytułowej wydrukowany czarną farbą. Po obu stronach drzeworytu czerwone inicjały tytulatury. Pod nim wiersz na cześć ordynariusza krakowskiego. Rubrycelę otwiera wiersz gratulacyjny dla nowego ordynariusza ułożony dla przez Jana Jurdzińskiego, podpisanego jako „devotissimus cliens”. Główny zrąb rubryceli: „Revolutiones annuae, festa mobilia”; kalendarz liturgiczny na każdy dzień roku; uzupełnienia do kalendarza liturgicznego obowiązujące w kolegiacie św. Jerzego na Wawelu; przypomnienia przepisów liturgicznych, komentarze do rubryk i zmiany liturgiczne; katalog prałatów i kanoników katedry wawelskiej opatrzony datą 1760; spis zmarłych w latach 1757-1759 księży diecezji krakowskiej; spis dni wolnych od pracy w sądzie biskupim oraz reklama książek wydanych przez drukarnię biskupią. Każda składka kalendarza, poczynając od drugiej, została włożona w czystą składkę folio, przeznaczoną do zapisywania notatek. Właściciel umieścił w nich informacje o odprawianych przez siebie intencjach mszalnych.

Oprawa: współczesna, tekturowa, oklejona papierem tłoczonym w roślinny ornament; w złym stanie.

Sygn. 10

11.

Rubricella dioecesis Cracoviensis [...] ad annum Domini MDCCLXI [...] conscripta [...]. [Joannes Cantius Jurdziński canonicus s. Georgorii, vicedecanus ecclesiae cathedralis Cracoviensis, Cracoviae 1760]. Na ostatniej stronie kalendarza: „Cracoviae. Typis Semin. Episc. Acad. Diaecesan”. $8^{\circ} \mathrm{nlb.}$

Treść: Herb bp. Kajetana Sołtyka (Sołtyk) w środku karty tytułowej wydrukowany czarną farbą. Po obu stronach drzeworytu czerwone inicjały tytulatury. Pod nim wiersz na cześć ordynariusza krakowskiego. Główny zrąb rubryceli: „Tabula ortus et occasus solis...”; „Revolutiones annuae, festa mobilia”; rozpoczynający się wierszem tekst ascetyczny o liturgii godzin; kalendarz liturgiczny na każdy dzień roku; uzupełnienia do kalendarza liturgicznego obowiązujące w kolegiacie św. Jerzego na Wawelu; przypomnienia przepisów liturgicznych; komentarze do rubryk i zmiany liturgiczne; katalog prałatów i kanoników katedry wawelskiej opatrzony datą 1761; teksty brewiarzowe dotyczące św. Barbary; dekret Klemensa XIII z 21 listopada 1759 r. w sprawie przywilejów ołtarzy, przy których sprawuje się mszę św. za zmarłych w kościołach parafialnych diecezji krakowskiej; spis zmarłych w 1759 r. duchownych diecezji krakowskiej; konstytucja Benedykta XIV (1747) dotycząca chrztu Żydów; spis dni wolnych od pracy w sądzie biskupim oraz reklama książek wydanych przez drukarnię biskupią; indeks książek wydanych przed Drukarnię Akademicko-Diecezjalną. W ostatniej części katalogu umieszczono dwie wolne karty na notatki.

Oprawa: współczesna, tekturowa, przednia część oklejona białym papierem, na niej właściciel ks. Jan Kanty Jurdziński napisał daty świąt ruchomych z 1761 r.; tylna część oklejona papierem z tłoczonym ornamentem roślinnym.

Sygn. 11

12.

Rubricella dioecesis Cracoviensis [...] ad annum Domini MDCCLXII [...] conscripta [...]. [Joannes Cantius Jurdziński canonicus s. Georgorii, vicedecanus ecclesiae cathedralis Cracoviensis, Cracoviae 1761]. $8^{\circ} \mathrm{nlb}$. 
Treść: Herb bp. Kajetana Sołtyka (Sołtyk) w środku karty tytułowej wydrukowany czarną farbą. Po obu stronach drzeworytu czerwone inicjały tytulatury. Pod nim wiersz na cześć ordynariusza krakowskiego. Główny zrąb rubryceli: „Tabula ortus et occasus solis...”; „Revolutiones annuae, festa mobilia”; wierszowany tekst ascetyczny o liturgii godzin; kalendarz liturgiczny na każdy dzień roku; wiersz o życiu kapłańskim; wiersz św. Bernarda o kontemplacji świata; uzupełnienia do kalendarza liturgicznego obowiązujące w kolegiacie św. Jerzego na Wawelu; przypomnienia przepisów liturgicznych; komentarze do rubryk i zmiany liturgiczne; brewe Klemensa XIII z 21 stycznia 1761 r. w sprawie odpustów na godzinę śmierci dla wszystkich wiernych diecezji krakowskiej, ze stosownymi zarządzeniami dla duchowieństwa podpisanymi przez ordynariusza; list bp. F. Potkańskiego do duchowieństwa i wiernych z 12 marca $1761 \mathrm{r}$. w sprawie misteriów odbywanych w okresie Wielkiego Tygodnia; katalog prałatów i kanoników katedry wawelskiej opatrzony datą 1761; spis zmarłych w 1760 i 1761 r. duchownych diecezji krakowskiej; indeks książek wydanych przed Drukarnię Akademicko-Diecezjalną. Każda składka kalendarza, poczynając od drugiej, została włożona w czystą składkę folio, przeznaczoną do zapisywania notatek. Zapisano na nich intencje mszalne na poszczególne dni roku, notując obok wielkości złożonej ofiary. Na wewnętrznej stronie przedniej okładki właściciel kalendarza umieścił notatki dotyczące intencji mszalnych; na wewnętrznej stronie tylnej okładki - rozliczenia związane z obowiązkami mszalnymi.

Oprawa: współczesna, tekturowa, oklejona amarantowym papierem tłoczonym w roślinny ornament.

Sygn. 12

13.

Rubricella dioecesis Cracoviensis [...] ad annum Domini MDCCLXIII [...] conscripta [...]. [Joannes Cantius Jurdziński canonicus s. Georgorii, vicedecanus ecclesiae cathedralis Cracoviensis, Cracoviae 1762]. $8^{\circ} \mathrm{nlb}$.

Uwagi: Brakuje ostatniej strony rubryceli.

Treść: Herb bp. Kajetana Sołtyka (Sołtyk) w środku karty tytułowej wydrukowany czarną farbą. Po obu stronach drzeworytu czerwone inicjały tytulatury. Pod nim wiersz na cześć ordynariusza krakowskiego. Główny zrąb rubryceli: „Tabula ortus et occasus solis...”; „Revolutiones annuae, festa mobilia”; kalendarz liturgiczny na każdy dzień roku; uzupełnienia do kalendarza liturgicznego obowiązujące w kolegiacie św. Jerzego na Wawelu; przypomnienia przepisów liturgicznych; komentarze do rubryk i zmiany liturgiczne; katalog prałatów i kanoników katedry wawelskiej opatrzony datą 1763; spis zmarłych w 1761 i 1762 r. duchownych diecezji krakowskiej; indeks książek wydanych przed Drukarnię Akademicko-Diecezjalną. Każda składka kalendarza, poczynając od drugiej, została włożona w czystą składkę folio, przeznaczoną do zapisywania notatek. Zapisano na nich w 1774 r. informacje dotyczące spraw gospodarczych.

Oprawa: nowa, płócienna.

Sygn. 13

14.

Rubricella dioecesis Cracoviensis [...] ad annum Domini MDCCLXIV [...] conscripta [...]. [Joannes Cantius Jurdziński canonicus s. Georgorii, vicedecanus ecclesiae cathedralis Cracoviensis, Cracoviae 1763]. $8^{\circ} \mathrm{nlb}$. 
Treść: Herb bp. Kajetana Sołtyka (Sołtyk) w środku karty tytułowej wydrukowany czarną farbą. Po obu stronach drzeworytu czerwone inicjały tytulatury. Pod nim wiersz na cześć ordynariusza krakowskiego. Główny zrąb rubryceli: „Revolutiones annuae, festa mobilia"; kalendarz liturgiczny na każdy dzień roku; uzupełnienia do kalendarza liturgicznego obowiązujące w kolegiacie św. Jerzego na Wawelu; przypomnienia przepisów liturgicznych; komentarze do rubryk i zmiany liturgiczne; katalog prałatów i kanoników katedry wawelskiej opatrzony datą 1764; spis zmarłych w 1762 i 1763 r. duchownych diecezji krakowskiej; indeks książek wydanych przed Drukarnię Akademicko-Diecezjalną; „Tabula ortus et occasus solis..."; reklama wydanego przez pijarów warszawskich zbioru nauk i kazań Samuela Wysockiego, pijara. Każda składka kalendarza, poczynając od drugiej, została włożona w czystą składkę folio, przeznaczoną do zapisywania notatek. Właściciel umieścił na nich nieliczne notatki dotyczące obowiązków mszalnych oraz powinności gospodarczych.

Oprawa: nowa, płócienna.

Sygn. 14

15.

Rubricella dioecesis Cracoviensis [...] ad annum Domini MDCCLXV [...] conscripta [...]. Joan[nes] Can[tius] Jos[ephus] Jurdzinski, c[anonicus] s. G[eorgii], vice-dec[anus] e[cclesiae] c[athedralis] C[racoviensis], [Cracoviae 1764]. $8^{\circ} \mathrm{nlb}$.

Uwagi: brak karty ostatnich składek.

Treść: Herb bp. Kajetana Sołtyka (Sołtyk) w środku karty tytułowej wydrukowany czarną farbą. Po obu stronach drzeworytu czerwone inicjały tytulatury. Pod nim wiersz na cześć ordynariusza krakowskiego. Główny zrąb rubryceli: „Revolutiones annuae, festa mobilia"; kalendarz liturgiczny na każdy dzień roku; uzupełnienia do kalendarza liturgicznego obowiązujące w kolegiacie św. Jerzego na Wawelu. Na wewnętrznej stronie pierwszej okładki znajduje się podpis właściciela rubryceli Cyryla Kossa, zakonnika klasztoru św. Marka w Krakowie.

Oprawa: tekturowa, orchowa, bez ozdób.

Sygn. 15

16.

Rubricella diaecesis Cracoviensis [...] ad annum Domini MDCCLXVI [...] conscripta [...]. Joan[nes] Can[tius] Jos[ephus] Jurdzinski, c[anonicus] s. G[eorgii], vice-dec[anus], [Cracoviae 1765]. $8^{\circ} \mathrm{nlb}$.

Uwagi: brak karty ostatnich składek.

Treść: Herb bp. Kajetana Sołtyka (Sołtyk) w środku karty tytułowej wydrukowany czarną farbą. Po obu stronach drzeworytu czerwone inicjały tytulatury. Pod nim wiersz na cześć ordynariusza krakowskiego. Główny zrąb rubryceli: „Revolutiones annuae, festa mobilia"; kalendarz liturgiczny na każdy dzień roku; uzupełnienia do kalendarza liturgicznego obowiązujące w kolegiacie św. Jerzego na Wawelu; uzupełnienia do brewiarza na święto bł. Wincentego Kadłubka ze stosownymi zarządzeniami; przypomnienia przepisów liturgicznych, komentarze do rubryk i zmiany liturgiczne; zarządzenia ordynariusza krakowskiego w sprawie odpustów in articulo mortis; katalog prałatów i kanoników katedry wawelskiej opatrzony datą 1766; spis zmarłych w 1764 i 1765 r. duchownych diecezji krakowskiej; „Lunationse”; „Tabula ortus et occasus solis...”. Każda składka kalendarza, poczynając od drugiej, została włożona w czystą składkę folio, przeznaczoną do zapisy- 
wania notatek. Właściciel umieścił na nich nieliczne notatki dotyczące obowiązków mszalnych.

Oprawa: tekturowa, amarantowa, bez ozdób.

Sygn. 16

17.

Rubricella dioecesis Cracoviensis [...] ad annum Domini MDCCLXVII [...] conscripta [...]. Joan[nes] Cant[ius] Joseph[us] Jurdziński, c[anonicus] s. G[eorgii], vice-dec[anus] e[cclesiae] c[athedralis] C[racoviensis], [Cracoviae 1766]. $8^{\circ} \mathrm{nlb}$.

Uwagi: brak ostatniej strony z „Tabula ortus et occasus solis...”.

Treść: Herb bp. Kajetana Sołtyka (Sołtyk) w środku karty tytułowej wydrukowany czarną farbą. Po obu stronach drzeworytu czerwone inicjały tytulatury. Pod nim wiersz na cześć ordynariusza krakowskiego. Główny zrąb rubryceli: „Revolutiones annuae, festa mobilia"; kalendarz liturgiczny na każdy dzień roku; uzupełnienia do kalendarza liturgicznego obowiązujące w kolegiacie św. Jerzego na Wawelu; dekrety dotyczące erygowania Bractwa Najświętszego Serca Pana Jezusa; instrukcja ordynariusza krakowskiego dotycząca prowadzenia kancelarii parafialnej oraz instrukcja do dziekanów dotycząca sprawozdań rocznych; katalog prałatów i kanoników katedry wawelskiej opatrzony datą 1767; przypomnienie niektórych przepisów liturgicznych; spis zmarłych w 1765 i 1766 r. duchownych diecezji krakowskiej; „Lunationse”. W pierwszej części kalendarza znajduje się pięć pustych kart na notatki. Na pierwszych dwóch właściciel przepisał fragment Elementarzyka ćwiczenia duchownego dominikanina Mikołaja z Mościsk, a na kolejnych zanotował informacje o obowiązkach mszalnych.

Oprawa: nowa, płócienna.

Sygn. 17

18.

Rubricella dioecesis Cracoviensis [...] ad annum Domini MDCCLXVIII [...] conscripta [...]. Joan[nes] Cant[ius] Joseph[us] Jurdziński, c[anonicus] s. G[eorgii], vice-dec[anus] e[cclesiae] c[athedralis] C[racoviensis], [Cracoviae 1767]. Na ostatniej stronie: Typis Stanislai Stachiewicz, S[acrae] R[egiae] M[aiestatis], typographi et Almae Universitatis Cracovinsis bibliopholae. $8^{\circ} \mathrm{nlb}$.

Treść: Herb bp. Kajetana Sołtyka (Sołtyk) w środku karty tytułowej wydrukowany czarną farbą. Po obu stronach drzeworytu czerwone inicjały tytulatury. Pod nim wiersz na cześć ordynariusza krakowskiego. Główny zrąb rubryceli: „Revolutiones annuae, festa mobilia"; kalendarz liturgiczny na każdy dzień roku; uzupełnienia do kalendarza liturgicznego obowiązujące w kolegiacie św. Jerzego na Wawelu; przypomnienie niektórych przepisów liturgicznych; dekret Kongregacji ds. Obrzędów w sprawie wspomnienia św. Joachima w Polsce i na Litwie; katalog prałatów i kanoników katedry wawelskiej opatrzony datą 1768; zarządzenie bp. F. Potkańskiego dotyczące wystawienia Najświętszego Sakramentu; spis zmarłych w 1766 i 1767 r. duchownych diecezji krakowskiej. W tomiku znajduje się dziewięć pustych kart na notatki. Właściciel rubryceli zasadniczo notował na nich cytaty oraz myśli z lektury Pisma Świętego i książek duchownych.

Oprawa: nowa, płócienna.

Sygn. 18 
19.

Ordo officii Divini pro diaecesi Cracoviensi [...] ad annum Domini MDCCLXIX [...] conscriptus [...]. Joan[nes] Cant[ius] Joseph[us] Jurdzienski, c[anonicus] s. G[eorgii], vice-dec[anus] e[cclesiae] c[athedralis] C[racoviensis], [Cracoviae 1768]. $8^{\circ} \mathrm{nlb}$.

Treść: Herb bp. Kajetana Sołtyka (Sołtyk) w środku karty tytułowej wydrukowany czarną farbą. Po obu stronach drzeworytu czarne inicjały tytulatury. Pod nim wiersz na cześć ordynariusza krakowskiego. Główny zrąb rubryceli: „Revolutiones annuae, festa mobilia"; kalendarz liturgiczny na każdy dzień roku; uzupełnienia do kalendarza liturgicznego obowiązujące w kolegiacie św. Jerzego na Wawelu; przypomnienie niektórych przepisów liturgicznych; dekret dotyczący obchodu święta św. Jana Kantego, patrona Polski; katalog prałatów i kanoników katedry wawelskiej opatrzony datą 1768; zarządzenie bp. F. Potkańskiego dotyczące obchodów pokanonizacyjnych św. Jana Kantego; spis zmarłych w 1767 i 1768 r. duchownych diecezji krakowskiej; słownik pojęć biblijnych, teologicznych i liturgicznych (A-E); katalog książek z Drukarni Akademickiej; „Tabula ortus et occasus solis...”. W tomiku znajdują się trzy puste karty na notatki. Właściciel rubryceli notował na nich wydatki oraz obowiązki mszalne.

Oprawa: tekturowa, szara, bez ozdób.

Sygn. 19

20.

Rubricella dioecesis Cracoviensis [...] ad annum Domini MDCCLXX [...] conscriptus [...]. Joann[es] Cantius Josephus Jurdzinski, c[anonicus] s. G[eorgii], vice-dec[anus] e[cclesiae] c[athedralis] C[racoviensis], [Cracoviae 1769]. $8^{\circ}$ nlb.

Treść: Herb bp. Kajetana Sołtyka (Sołtyk) w środku karty tytułowej wydrukowany czarną farbą. Po obu stronach drzeworytu czarne inicjały tytulatury. Pod nim wiersz na cześć ordynariusza krakowskiego. Główny zrąb rubryceli: „Revolutiones annuae, festa mobilia"; kalendarz liturgiczny na każdy dzień roku; uzupełnienia do kalendarza liturgicznego obowiązujące w kolegiacie św. Jerzego na Wawelu; przypomnienie niektórych przepisów liturgicznych; katalog prałatów i kanoników katedry wawelskiej opatrzony datą 1770; spis zmarłych w 1768 i 1769 r. duchownych diecezji krakowskiej; słownik pojęć biblijnych, teologicznych i liturgicznych (F-L); „,Tabula ortus et occasus solis...”. W tomiku znajduje się dziewięć pustych kart na notatki. Właściciel rubryceli notował na nich wydatki.

Oprawa: tekturowa, czerwona, ozdobiona ślepą bordiurą roślinną.

Sygn. 20

\section{1.}

Rubricella diaecesis Cracoviensis [...] ad annum Domini MDCCLXXI [...] conscripta [...]. Joan[nes] Can[tius] Jos[ephus] Jurdziński, c[anonicus] s. G[eorgii], vice-dec[anus] e[cclesiae] c[athedralis] C[racoviensis], [Cracoviae 1770]. $8^{\circ} \mathrm{nlb}$.

Treść: Herb bp. Kajetana Sołtyka (Sołtyk) w środku karty tytułowej wydrukowany czarną farbą. Po obu stronach drzeworytu czarne inicjały tytulatury. Pod nim wiersz na cześć ordynariusza krakowskiego. Główny zrąb rubryceli: „Revolutiones annuae, festa mobilia"; kalendarz liturgiczny na każdy dzień roku; uzupełnienia do kalendarza liturgicznego obowiązujące w kolegiacie św. Jerzego na Wawelu; dekrety rzymskie o wprowadzeniu do kalendrza liturgicznego nowokanizowanego św. Józefa Kalasancjusza i św. Jana Kantego; katalog prałatów i kanoników katedry wawelskiej opatrzony datą 1771; spis zmarłych w 1769 i 1770 r. duchownych diecezji krakowskiej; kontynuacja słownika etymologiczne- 
go pojęć używanych w brewiarzu i mszale rzymskim; „Lunationes” z 1771 r.; „Tabula ortus et occasus solis...”; katalog książek religijnych księgarni Fabiana Sebastiana Drelinkiewicza; katalog książek drukarni Seminarium Akademickiego. Każda składka kalendarza, poczynając od drugiej, została włożona w czystą składkę folio, przeznaczoną do zapisywania notatek. Właściciel umieścił na nich zapiski dotyczące obowiązków mszalnych oraz wydatków kuchennych.

Oprawa: nowa, płócienna.

Sygn. 21

22.

Rubricella dioecesis Cracoviensis [...] ad annum Domini MDCCLXXII [...] conscripta [...]. Joan[nes] Can[tius] Jos[ephus] Jurdziński, c[anonicus] s. G[eorgii], vice-dec[anus] e[cclesiae] c[athedralis] C[racoviensis], [Cracoviae 1771]. $8^{\circ} \mathrm{nlb}$.

Treść: Herb bp. Kajetana Sołtyka (Sołtyk) w środku karty tytułowej wydrukowany czarną farbą. Po obu stronach drzeworytu czerwone inicjały tytulatury. Pod nim wiersz na cześć ordynariusza krakowskiego. Główny zrąb rubryceli: „Revolutiones annuae, festa mobilia"; kalendarz liturgiczny na każdy dzień roku; uzupełnienia do kalendarza liturgicznego obowiązujące w kolegiacie św. Jerzego na Wawelu; uzupełnienia do brewiarza, przypomnienia przepisów liturgicznych; dekrety dotyczące kultu św. Joanny Franciszki de Chantal i św. Jana Kantego; katalog prałatów i kanoników katedry wawelskiej; spis zmarłych w 1769, 1770 i 1771 r. duchownych diecezji krakowskiej; dekret w sprawie wpisania kolejnych książek do katalogu ksiąg zakazanych; „Tabula ortus et occasus solis...”; katalog książek religijnych księgarni Ignacego Grebela; katalog książek drukarni Seminarium Akademickiego. Każda składka kalendarza, poczynając od drugiej, została włożona w czystą składkę folio, przeznaczoną do zapisywania notatek. Nie zostały one zapisane. Oprawa: nowa, płócienna.

Sygn. 22

23.

Rubricella dioecesis Cracoviensis [...] ad annum Domini MDCCLXXIII [...] conscripta [...]. Joan[nes] Can[tius] Jos[ephus] Jurdziński, c[anonicus] s. G[eorgii], vice-dec[anus] e[cclesiae] c[athedralis] C[racoviensis], [Cracoviae 1772]. $8^{\circ}$ nlb.

Treść: Herb bp. Kajetana Sołtyka (Sołtyk) w środku karty tytułowej wydrukowany czarną farbą. Po obu stronach drzeworytu czerwone inicjały tytulatury. Pod nim wiersz na cześć ordynariusza krakowskiego. Główny zrąb rubryceli: „Revolutiones annuae, festa mobilia"; kalendarz liturgiczny na każdy dzień roku; uzupełnienia do kalendarza liturgicznego obowiązujące w kolegiacie św. Jerzego na Wawelu; uzupełnienia do brewiarza, przypomnienia przepisów liturgicznych; katalog prałatów i kanoników katedry wawelskiej; spis zmarłych w 1771 i 1772 r. duchownych diecezji krakowskiej; „Tabula ortus et occasus solis..."; katalog książek religijnych księgarni Ignacego Grebela. Każda składka kalendarza, poczynając od drugiej, została włożona w czystą składkę folio, przeznaczoną do zapisywania notatek. W większości karty nie są zapisane. Na pierwszej stronie oraz na ostatniej stronie katalogu zmarłych znajduje się podpis właściciela rubryceli: Adriana Bronkalskiego z krakowskiego klasztoru Marków.

Oprawa: tekturowa w kolorze czerwonym, z wyciskaną na brzegach złotą bordiurą z ornamentem geometrycznym.

Sygn. 23 


\section{4.}

[Rubricella dioecesis Cracoviensis... ad annum Domini MDCCLXXIV [...] conscripta [...]. [Joannes Cantius Josephus Jurdziński, canonicus s. Georgii, vice-decanus ecclesiae cathedralis Cracoviensis, Cracoviae 1773]. $8^{\circ} \mathrm{nlb}$. Na ostatniej stronie: „Typis Collegii Majoris Universitatis Cracoviensis”.

Uwagi: brak karty tytułowej.

Treść: W zachowanej części kalendarz liturgiczny na każdy dzień roku; uzupełnienia do kalendarza liturgicznego obowiązujące w kolegiacie św. Jerzego na Wawelu; przypomnienia dekretów Kongregacji ds. Obrzędów w sprawie przepisów liturgicznych (m.in. o mszy św. roratniej); katalog prałatów i kanoników katedry wawelskiej; spis zmarłych w 1772 i 1773 r. duchownych diecezji krakowskiej; „Lunationes” na 1774 r.; „Tabula ortus et occasus solis..."; katalog książek religijnych księgarni Ignacego Grebela. Każda składka kalendarza, poczynając od drugiej, została włożona w czystą składkę folio, przeznaczoną do zapisywania notatek. Wykorzystano je jako brudnopis akt metrykalnych (akta chrztu i ślubów z 1774 i 1775 r.) oraz miejsce na notatki finansowe. Ze wspomnianych zapisów metrykalnych wynika, że właścicielem rubryceli był ks. Sebastian Gorowicz (Gurowicz, pleban z Przytkowic.

Oprawa: nowa, płócienna.

Sygn. 24

25.

Rubricella dioecesis Cracoviensis [...] ad annum Domini MDCCLXXVI [...] conscripta [...]. Joan[nes] Can[tius] Jos[ephus] Jurdziński, c[anonicus] s. G[eorgii], vice-dec[anus] e[cclesiae] c[athedralis] C[racoviensis], [Cracoviae 1775]. $8^{\circ} \mathrm{nlb}$.

Treść: Herb bp. Kajetana Sołtyka (Sołtyk) w środku karty tytułowej wydrukowany czarną farbą. Po obu stronach drzeworytu czerwone inicjały tytulatury. Pod nim wiersz na cześć ordynariusza krakowskiego. Główny zrąb rubryceli: „Revolutiones annuae, festa mobilia"; kalendarz liturgiczny na każdy dzień roku; uzupełnienia do kalendarza liturgicznego obowiązujące w kolegiacie św. Jerzego na Wawelu; katalog prałatów i kanoników katedry wawelskiej; list pasterski bp. K.I. Sołtyka w sprawie redukcji obowiązkowych świąt z 6 lipca 1775 r.; uzupełnienia do brewiarza w święto Apostołów Piotra i Pawła oraz święto św. Szczepana; przypomnienie niektórych przepisów liturgicznych; spis zmarłych w 1774 i 1775 r. duchownych diecezji krakowskiej; „Tabula ortus et occasus solis...”. Każda składka kalendarza, poczynając od drugiej, została włożona w czystą składkę folio, przeznaczoną do zapisywania notatek. Właściciel rubryceli wykorzystał ją do zapisania: przepisu leku na „kurcz, paraliż, reumatyzm, podagrę”; wydatków poniesionych „,na siostrzenicę moją Sucholską zamyślającą wstąpić do klasztoru”; wydatków na „pocztę”, wydatków związanych z gospodarstwem.

Oprawa: tekturowa w kolorze czerwonym, z wyciskaną na brzegach złotą bordiurą o motywach roślinnych.

Sygn. 25

26.

Rubricella diaecesis Cracoviensis [...] ad annum Domini MDCCLXXVII [...] conscripta [...]. Joan[nes] Can[tius] Jos[ephus] Jurdziński, c[anonicus] s. G[eorgii], vice-dec[anus] e[cclesiae] c[athedralis] C[racoviensis], [Cracoviae 1776]. $8^{\circ}$ 
nlb. Na ostatniej stronie: „W drukarni kolegium większego Akademii Krakowskiej. Nakładem Ignacego Grebela bibliopoli I. K. Mci.”.

Treść: Herb bp. Kajetana Sołtyka (Sołtyk) w środku karty tytułowej wydrukowany czarną farbą. Po obu stronach drzeworytu czerwone inicjały tytulatury. Pod nim wiersz na cześć ordynariusza krakowskiego. Główny zrąb rubryceli: „Revolutiones annuae, festa mobilia"; kalendarz liturgiczny na każdy dzień roku; uzupełnienia do kalendarza liturgicznego obowiązujące w kolegiacie św. Jerzego na Wawelu; katalog prałatów i kanoników katedry wawelskiej; „przestrogi” ordynariusza zredagowane przez bp. J. Olechowskiego dla pasterzy w sprawie zniesienia w obu częściach diecezji krakowskiej zwyczajów biczowania się w czasie nabożeństw wielkopostnych („,kapnicy”) oraz wprowadzenia jednolitych przepisów postnych obowiązujących w Kościele (pozwolenie na używanie potraw „mlecznych czyli maślanych"); spis zmarłych w 1775 i 1776 r. duchownych diecezji krakowskiej; „Tabula ortus et occasus solis...”; katalog książek religijnych księgarni Ignacego Grebela. Po trzech pierwszych składkach znajdują się czyste karty na notatki. Właściciel rubryceli wykorzystał je do notatek dotyczących zmarłych oraz obowiązków mszalnych. $\mathrm{Z}$ zapisków tych wynika, że z egzemplarza tego korzystał proboszcz z Mikluszowic. Był nim wówczas ks. Szymon Banaczkowski.

Oprawa: tekturowa okładkowa oklejona papierem „marmurkowym”.

Sygn. 26

\section{7.}

Rubricella diaecesis Cracoviensis [...] ad annum Domini MDCCLXXVIII [...] conscripta [...]. Joan[nes] Can[tius] Jos[ephus] Jurdziński, c[anonicus] s. G[eorgii], vice-dec[anus] e[cclesiae] c[athedralis] C[racoviensis], [Cracoviae 1777]. $8^{\circ}$ nlb. Na ostatniej stronie: „W Krakowie, w drukarni Seminar. Biskup. Akademickiey. Nakładem JP. Ignacego Grebela bibliopoli Jego Kroleskiey MCi”.

Treść: Herb bp. Kajetana Sołtyka (Sołtyk) w środku karty tytułowej wydrukowany czarną farbą. Po obu stronach drzeworytu czerwone inicjały tytulatury. Pod nim wiersz na cześć ordynariusza krakowskiego. Główny zrąb rubryceli: „Revolutiones annuae, festa mobilia"; kalendarz liturgiczny na każdy dzień roku; uzupełnienia do kalendarza liturgicznego obowiązujące w kolegiacie św. Jerzego na Wawelu; przypomnienia przepisów dotyczących obchodów świątecznych; katalog prałatów i kanoników katedry wawelskiej; „,zalecenia" ordynariusza zredagowane bp. J. Olechowskiego dla pasterzy w sprawie: (1.) podporządkowania się przepisom kościelnym $\mathrm{w}$ sprawie świąt zniesionych, (2.) zakazowi traktowania petyty jako zobowiązania finansowego parafian, a nie przywileju, (3.) ostrzeżenie przed Stanisławem Morawskim fałszerzem dokumentów; spis zmarłych w latach 1775-1777 duchownych diecezji krakowskiej; „Tabula ortus et occasus solis...”; katalog książek religijnych księgarni Ignacego Grebela. Na marginesach katalogu znajdują się notatki dotyczące intencji mszalnych.

Oprawa: tekturowa w kolorze orchowym, z wyciskaną na brzegach ślepą bordiurą o motywach roślinnych.

Sygn. 27

28.

Rubricella diaecesis Cracoviensis [...] ad annum Domini MDCCLXXX [...] conscripta [...]. [Joannes Cantius Josephus Jurdziński, canonicus s. Georgii, vice-decanus ecclesiae cathedralis Cracoviensis, Cracoviae 1779]. $8^{\circ}$, s. 115 (kalendarza 
i przepisów liturgicznych), s. 2 (katalogu kanoników), nlb (innych dodatków), s. 61 (katalogu książek).

Treść: Na drugiej stronie herb bp. Kajetana Sołtyka (Sołtyk) wydrukowany czarną farbą. Po obu stronach drzeworytu czerwone inicjały tytulatury. Pod nim wiersz na cześć ordynariusza krakowskiego oraz nazwisko redaktora rubryceli ks. Jana Kantego Józefa Jurdzińskiego, kanonika kolegiaty św. Jerzego na Wawelu oraz wicedziekana katedry wawelskiej. Główny zrąb rubryceli: „Revolutiones annuae, festa mobilia”; kalendarz liturgiczny na każdy dzień roku; uzupełnienia do kalendarza liturgicznego obowiązujące w kolegiacie św. Jerzego na Wawelu; przypomnienia modlitw oraz czytania brewiarzowe na święto bł. Szymona z Lipnicy i zarządzenia rzymskie w tej sprawie; przypomnienie niektórych przepisów liturgicznych; katalog prałatów i kanoników katedry wawelskiej; ,zalecenia” ordynariusza zredagowane przez bp. J. Olechowskiego dla pasterzy w sprawie: (1) pozwolenia zakonnikom na kwestę $\mathrm{w}$ dworach, z podtrzymaniem zakazu kwesty wśród chłopów, (2) zakazu zbierania darów w naturze w czasie wypominek, (3) zakazu wykorzystania kun przy kościołach do wymierzania kar, (4) konieczności przestrzegania wymogów sanitarnych przy grzebaniu zmarłych, (5) zasad poboru dziesięciny, (6) płacenia Subsidium charitativum; spis zmarłych w 1776, 1777, 1778 i 1779 r. duchownych diecezji krakowskiej; „Tabula ortus et occasus solis...”. Osobną częścią tomiku jest wydany z własną kartą tytułową, datowany na 1779 r., obszerny katalog wydawnictw możliwych do zakupienia w księgarni Ignacego Grebela. Po każdej składce znajdują się czyste karty na notatki. Właściciel rubryceli nie poczynił na nich żadnych notatek.

Oprawa: tekturowa w kolorze popielatym, z wyciskaną na brzegach złotą bordiurą z ornamentami geometrycznymi.

Sygn. 28

29.

Ordo officii Divini pro diaecesi Cracoviensi [...] ad annum Domini MDCCLXXXII [...] conscriptus [...]. Joan[nes] Can[tius] Jos[ephus] Jurdziński, c[anonicus] s. G[eorgii], vice-dec[anus] e[cclesiae] c[athedralis] C[racoviensis], [Cracoviae 1781$] .8^{\circ} \mathrm{nlb}$.

Treść: Herb bp. Kajetana Sołtyka (Sołtyk) w środku karty tytułowej wydrukowany czarną farbą. Po obu stronach drzeworytu czerwone inicjały tytulatury. Pod nim wiersz na cześć ordynariusza krakowskiego. Główny zrąb rubryceli: „Revolutiones annuae, festa mobilia"; kalendarz liturgiczny na każdy dzień roku; uzupełnienia do kalendarza liturgicznego obowiązujące w kolegiacie św. Jerzego na Wawelu; przypomnienie niektórych przepisów liturgicznych; katalog prałatów i kanoników katedry wawelskiej; spis zmarłych w latach 1779-1781 r. duchownych diecezji krakowskiej; suplement I. do spisu książek znajdujących się na składzie w księgarni Ignacego Grebela.

Oprawa: nowa, płócienna.

Sygn. 29

30.

Ordo officii Divini pro diaecesi Cracoviensi [...] ad annum Domini MDCCLXXXIII [...] conscriptus [...], Cracoviae [1782]. Joan[nes] Can[tius] Josephus Jurdziński, c[anonicus] s. G[eorgii], vice-dec[anus] e[cclesiae] c[athedralis] C[racoviensis]. $8^{\circ} \mathrm{nlb}$. 
Treść: Główny zrąb rubryceli: „Revolutiones annuae, festa mobilia”; kalendarz liturgiczny na każdy dzień roku; uzupełnienia do kalendarza liturgicznego obowiązujące w kolegiacie św. Jerzego na Wawelu; przypomnienie niektórych przepisów liturgicznych; katalog prałatów i kanoników katedry wawelskiej; spis zmarłych w 1781 i 1782 r. duchownych diecezji krakowskiej; suplement II do spisu książek znajdujących się na składzie w księgarni Ignacego Grebela; dekret Kongregacji ds. Obrzędów w sprawie sprawowania oficjum i mszy św. cichej o św. Janie Kantym. Na początku tomiku znajdują się dwie czyste karty przeznaczone do zapisywania notatek. Właściciel wykorzystał je do zanotowania informacji o obowiązkach mszalnych i sprawach finansowych. Na wewnętrznej stronie okładki podpisał się właściciel kalendarza ks. Marcin Skublewski (Skutlewski), mansjonarz w Stopnicy.

Oprawa: tekturowa w kolorze różowym, z wyciskaną na brzegach złotą bordiurą o motywach roślinnych.

Sygn. 30

31.

Ordo officii Divini pro diaecesi Cracoviensi [...] ad annum Domini MDCCLXXXV [...] conscriptus [...], per A[dmodum] R[everendum] $\mathrm{D}$ [ominum] Thomam Mączyński, c[anonicum] s. G[eorgii], vice-dec[anum] e[ecclesiam] c[athedralem] Crac[oviensiam], Cracoviae [1784]. $8^{\circ} \mathrm{nlb}$. Na stronie tytułowej wydawca: „Typis Scholae Principis Regni Universitatis Cracoviensis”.

Treść: Główny zrąb rubryceli: „Revolutiones annuae, festa mobilia”; kalendarz liturgiczny na każdy dzień roku; uzupełnienia do kalendarza liturgicznego obowiązujące w kolegiacie św. Jerzego na Wawelu; przypomnienie niektórych przepisów liturgicznych; katalog prałatów i kanoników katedry wawelskiej; spis zmarłych w latach 1780-1784 r. duchownych diec. krakowskiej; „Tabula ortus et occasus solis...”.

Oprawa: tekturowa w kolorze orchy, z wyciskaną na brzegach złotą bordiurą o motywach roślinnych oraz na środku okładki złotą koroną królewską.

Sygn. 31

32.

Directorium officii Divini pro diaecesi Cracoviensi [...] ad annum Domini MDCCLXXXVI [...] conscriptum [...], per $\mathrm{A}$ [dmodum] $\mathrm{R}$ [everendum] $\mathrm{D}$ [ominum] Thomam Mączyński, c[anonicum] s. G[eorgii], vice-dec[anum] e[ecclesiam] c[athedralem] Crac[oviensiam], Cracoviae [1785]. $8^{\circ} \mathrm{nlb}$. Na stronie tytułowej wydawca: „Typis Scholae Principis Regni Universitatis Cracoviensis”.

Treść: Główny zrąb rubryceli: „Revolutiones annuae, festa mobilia”; kalendarz liturgiczny na każdy dzień roku; przypomnienie niektórych przepisów liturgicznych; katalog prałatów i kanoników katedry wawelskiej; spis zmarłych w latach 1782-1785 r. duchownych diecezji krakowskiej; „Tabula ortus et occasus solis...”; reklama drukarni i księgarni Ignacego Grebela.

Oprawa: nowa, płócienna.

Sygn. 32

33.

Ordo officii Divini pro diaecesi Cracoviensi [...] ad annum Domini MDCCLXXXVII [...]. conscriptus [...], per Ill[ustrissimum] A[dmodum] R[everendum] 
$\mathrm{D}$ [ominum] Thomam Mączyński, c[anonicum] s. G[eorgii], vice-dec[anum] e[ecclesiam] c[athedralem] Crac[oviensiam], Cracoviae [1786]. $8^{\circ} \mathrm{nlb}$. Na stronie tytułowej wydawca: „Typis Scholae Principis Regni Univer. Crac.”.

Treść: Główny zrąb rubryceli: „Revolutiones annuae, festa mobilia”; kalendarz liturgiczny na każdy dzień roku; przypomnienie niektórych przepisów liturgicznych; katalog prałatów i kanoników katedry wawelskiej; spis zmarłych 1783, 1785 i 1786 r. duchownych diecezji krakowskiej; „Tabula ortus et occasus solis...”; katalog druków wytłoczonych w drukarni Ignacego Grebela.

Oprawa: szary papier.

Sygn. 33

34.

Directorium officii Divini pro diaecesi Cracoviensi [...] ad annum Domini MDCCLXXXVIII [...] conscriptum [...], per Ill[ustrissimum] A[dmodum] R[everendum] D[ominum] Thomam Mączyński, c[anonicum] s. G[eorgii], vice-decanum eccl[esiaam] cath[edralem] Cracov[iensiam], Cracoviae [1787]. $8^{\circ}$ nlb. Na stronie tytułowej wydawca: „Typis Scholae Principis Regni Universitatis Crac.”. Treść: Główny zrąb rubryceli: „Revolutiones annuae, festa mobilia”; kalendarz liturgiczny na każdy dzień roku; przypomnienie niektórych przepisów liturgicznych; katalog prałatów i kanoników katedry wawelskiej; spis zmarłych 1786 i 1787 r. duchownych diecezji krakowskiej; „Tabula ortus et occasus solis...”. Każda składka kalendarza, poczynając od drugiej, została włożona w czystą składkę folio, przeznaczoną do zapisywania notatek. Właściciel wykorzystał tylko pierwszą kartę, pisząc na niej spis otrzymanych dziesięcin. Oprawa: tekturowa w kolorze popielatym, z wyciskaną na brzegach złotą bordiurą o motywach roślinnych oraz na środku okładki złotą koroną królewską.

Sygn. 34

35.

Directorium officii Divini pro diaecesi Cracoviensi [...] ad annum Domini MDCCXC [...] conscriptum [...], per Ill[ustrissimum] A[dmodum] R[everendum] D[ominum] Thomam Mączyński, c[anonicum] s. G[eorgii], vice-decanum eccl[esiam] cath[edralem] Crac[oviensiam], Cracoviae [1789]. $8^{\circ} \mathrm{nlb}$. Na stronie tytułowej wydawca: „Typis Scholae Principis Regni Universitatis Crac.”.

Treść: Główny zrąb rubryceli: „Revolutiones annuae, festa mobilia”; kalendarz liturgiczny na każdy dzień roku; przypomnienie niektórych przepisów liturgicznych; katalog prałatów i kanoników katedry wawelskiej; spis zmarłych w 1788 i 1789 r. duchownych diecezji krakowskiej; „Tabula ortus et occasus solis...”. Oddzielną część tomiku stanowi katalog polskich książek, które wydrukowano w 1789 r. w drukarni Ignacego Grebela.

Oprawa: różowy papier.

Sygn. 35

36.

Ordo officii Divini pro diaecesi Cracoviensi [...] ad annum Domini MDCCXCI [...] conscriptum [...], per Ill[ustrissimum] A[dmodum] R[everendum] D[ominum] Thomam Mączyński, c[anonicum] s. G[eorgii], vice-decanum cath[edra] 
lem Cracov[iensiam], Cracoviae [1790]. $8^{\circ} \mathrm{nlb}$. Na stronie tytułowej wydawca: „Typis Scholae Principis Regni Universitatis Crac.”.

Treść: Główny zrąb rubryceli: „Revolutiones annuae, festa mobilia”; kalendarz liturgiczny na każdy dzień roku; przypomnienie niektórych przepisów liturgicznych; katalog prałatów i kanoników katedry wawelskiej; katalog prałatów i kanoników kolegiaty sandomierskiej; spis zmarłych w 1788-1790 r. duchownych diecezji krakowskiej; „Tabula ortus et occasus solis...”. Każda składka kalendarza, poczynając od drugiej, została włożona w czystą składkę folio, przeznaczoną do zapisywania notatek. Właściciel wykorzystał je do notatek gospodarczych oraz informacji dotyczących pogody. Ponadto na obu wklejkach okładkowych zanotował rachunki dotyczące powinności mszalnych.

Oprawa: tektura oklejona orchowym papierem z tłoczoną na brzegach złotą bordiurą roślinną; na środku okładki odciśnięto tłok z ornamentem roślinnym.

Sygn. 36

37.

Directorium officii Divini pro diaecesi Cracoviensi [...] ad annum Domini MDCCXCII [...] conscriptum [...]. Thomas Mączyński, c[anonicu] s. G[eorgii], vicedec[anus] e[cclesiae] c[athedralis] Crac[oviensis], [Cracoviae 1791]. $8^{\circ} \mathrm{nlb}$.

Treść: Herb bp. Feliksa Turskiego (Rogala) w środku karty tytułowej wydrukowany czarną farbą. Po obu stronach drzeworytu czarne inicjały tytulatury. Pod nim wiersz na cześć ordynariusza krakowskiego. Główny zrąb rubryceli: „Revolutiones annuae, festa mobilia"; kalendarz liturgiczny na każdy dzień roku; przypomnienie niektórych przepisów liturgicznych;katalog prałatówikanoników katedry wawelskiej; spiszmarłych w 1790i1791 r. duchownych diecezji krakowskiej; „Lunationes” na 1792 r.; „Tabula ortus et occasus solis...". Każda składka kalendarza, poczynając od drugiej, została włożona w czystą składkę folio, przeznaczoną do zapisywania notatek. Zapisana została tylko jedna z nich (uzupełnienia do kalendarza liturgicznego dotyczącego kościoła Mariackiego w Krakowie na miesiąc lipiec i sierpień oraz powinności dotyczące mszy św. fundacyjnych). Ponadto właściciel tego egzemplarza umieścił kilkanaście notatek na okładkach, wklejkach okładowych i niezadrukowanych częściach kalendarza. Wśród nich są informacje o: pożyczce, obowiązkach mszalnych, zmarłych w 1792 r. księżach i świeckich - obywateli miasta Krakowa, oraz składzie Rady Miejskiej.

Oprawa: tekturowa w kolorze różowym, z wyciskaną na brzegach podwójną złotą bordiurą o motywach roślinnych i geometrycznych. Na środku okładki wytłoczony złoty ornament roślinny.

Sygn. 37

38.

Ordo officii Divini pro diaecesi Cracoviensi [...] ad annum Domini MDCCXCIII [...] conscriptus [...]. Thomas Mączyński, c[anonicu] s. G[eorgii], vice-dec[anus] e[cclesiae] c[athedralis] Crac[oviensis], [Cracoviae 1792]. $8^{\circ} \mathrm{nlb}$.

Treść: Herb bp. Feliksa Turskiego (Rogala) w środku karty tytułowej wydrukowany czarną farbą. Po obu stronach drzeworytu czarne inicjały tytulatury. Pod nim wiersz na cześć ordynariusza krakowskiego. Główny zrąb rubryceli: „Revolutiones annuae, festa mobilia"; kalendarz liturgiczny na każdy dzień roku; przypomnienie niektórych przepisów liturgicznych; katalog prałatów i kanoników katedry wawelskiej; spis zmarłych w latach 1790-1792 r. duchownych diecezji krakowskiej; „Tabula ortus et occasus solis...”. Na 
marginesie kalendarza właściciel poczynił nieliczne poprawki i uzupełnienia do przepisów. Biorąc pod uwagę charakter notatek oraz inne zapiski w kolejnych rocznikach przechowywanych w krakowskim zbiorze, może to być korekta poczyniona przez redaktora. Oprawa: tekturowa w kolorze różowym, z wyciskaną na brzegach podwójną złotą bordiurą o motywach roślinnych i geometrycznych.

Sygn. 38

39.

Directorium officii Divini pro diaecesi Cracoviensi [...] ad annum Domini MDCCXCIV [...] conscriptum [...]. Thomas Mączyński, c[anonicu] s. G[eorgii], vice-dec[anus] e[cclesiae] c[athedralis] Crac[oviensis], [Cracoviae 1793]. $8^{\circ} \mathrm{nlb}$.

Treść: Herb bp. Feliksa Turskiego (Rogala) w środku karty tytułowej wydrukowany czarną farbą. Po obu stronach drzeworytu czarne inicjały tytulatury. Pod nim wiersz na cześć ordynariusza krakowskiego. Główny zrąb rubryceli: „Revolutiones annuae, festa mobilia"; kalendarz liturgiczny na każdy dzień roku; przypomnienie niektórych przepisów liturgicznych; katalog prałatów i kanoników katedry wawelskiej; spis zmarłych w 1791, 1792 i 1793 r. duchownych diecezji krakowskiej; ,Tabula ortus et occasus solis...”.

Oprawa: nowa, płócienna.

Sygn. 39

40.

Directorium officii Divini pro diaecesi Cracoviensi [...] ad annum Domini MDCCXCV [...] conscriptum [...]. Thomas Komperdowicz, c[anonicu] s. G[eorgii], vice-dec[anus] e[cclesiae] c[athedralis] Crac[oviensis], [Cracoviae 1794]. $8^{\circ} \mathrm{nlb}$.

Treść: Herb bp. Feliksa Turskiego (Rogala) w środku karty tytułowej wydrukowany czarną farbą. Po obu stronach drzeworytu czarne inicjały tytulatury. Pod nim wiersz na cześć ordynariusza krakowskiego. Główny zrąb rubryceli: „Revolutiones annuae, festa mobilia"; kalendarz liturgiczny na każdy dzień roku; przypomnienie niektórych przepisów liturgicznych; katalog prałatów i kanoników katedry wawelskiej; spis zmarłych w latach 1792-1794 r. duchownych diecezji krakowskiej; jednostronicowy katalog książek znajdujących się w księgarni Jana Maya, (ul. Floriańska nr 511); „Tabula ortus et occasus solis...". Po raz pierwszy pojawia się w rubryceli errata. Na marginesie kalendarza znajduje się korekta tomu, o czym świadczy notka na pierwszej stronie: „probatio calami”.

Oprawa: tekturowa obłożona amarantową tkaniną, z wyciskaną na brzegach złotą bordiurą o motywach roślinnych.

Sygn. 40

41.

Directorium officii Divini pro diaecesi Cracoviensi [...] ad annum Domini MDCCXCVI [...] conscriptum [...]. Thomas Komperdowicz, c[anonicu] s. G[eorgii], vice-dec[anus] e[cclesiae] c[athedralis] Crac[oviensis], [Cracoviae 1795]. $8^{\circ} \mathrm{nlb}$.

Treść: Herb bp. Feliksa Turskiego (Rogala) w środku karty tytułowej wydrukowany czarną farbą. Po obu stronach drzeworytu czarne inicjały tytulatury. Pod nim wiersz na cześć ordynariusza krakowskiego. Główny zrąb rubryceli: „Revolutiones annuae, festa mobilia"; kalendarz liturgiczny na każdy dzień roku; przypomnienie niektórych przepisów liturgicznych; katalog prałatówikanoników katedrywawelskiej; spis zmarłychw 1794i1795r. duchownych diecezji krakowskiej; „Tabula ortus et occasus solis...”. Na marginesie ka- 
lendarza znajduje się korekta tomu, o czym świadczy notka na ostatniej stronie kalendarza liturgicznego (,probatio calami”). Na wewnętrznej stronie okładki znajdują się notatki dotyczące obowiązków mszalnych.

Oprawa: tekturowa, orchowa, z wyciskaną na brzegach złotą bordiurą o motywach geometrycznych i wytłoczonymi na rogach ornamentami roślinnymi.

Sygn. 41

42.

[Directorium officii Divini pro diaecesi Cracoviensi ad annum Domini MDCCXCVII conscriptum]. [Thomas Komperdowicz, canonicu s. Georgii, vice-decanus ecclesiae cathedralis Cracoviensis, Cracoviae 1795]. $8^{\circ} \mathrm{nlb}$

Uwagi: brak karty tytułowej i ostatniej strony.

Treść: W zachowanej części rubryceli znajdują się: kalendarz liturgiczny na każdy dzień roku; przypomnienie niektórych przepisów liturgicznych; katalog prałatów i kanoników katedry wawelskiej; spis zmarłych w 1795 i 1796 r. duchownych diecezji krakowskiej.

Oprawa: nowa, płócienna.

Sygn. 42

43.

Directorium officii Divini pro diaecesi Cracoviensi [...] ad annum Domini MDCCXCVIII [...] conscriptum [...]. Thomas Komperdowicz, c[anonicu] s. G[eorgii], vice-dec[anus] e[cclesiae] c[athedralis] C[racoviensis], [Cracoviae 1797]. $8^{\circ} \mathrm{nlb}$.

Treść: Herb bp. Feliksa Turskiego (Rogala) w środku karty tytułowej wydrukowany czarną farbą. Po obu stronach drzeworytu czarne inicjały tytulatury. Pod nim wiersz na cześć ordynariusza krakowskiego. Główny zrąb rubryceli: „Revolutiones annuae, festa mobilia"; kalendarz liturgiczny na każdy dzień roku; przypomnienie niektórych przepisów liturgicznych; katalog prałatów i kanoników katedry wawelskiej; spis zmarłych w latach 1795-1797 r. duchownych diecezji krakowskiej; „Lunationes”; „Tabula ortus et occasus solis...". Po każdej składce znajdują się czyste karty na notatki. Właściciel rubryceli nie poczynił na nich żadnych notatek.

Oprawa: tekturowa w kolorze orchowym, z wyciskaną na brzegach podwójną złotą bordiurą o motywach roślinnych i geometrycznych. Na środku okładki wytłoczono złotą koronę.

Sygn. 43

\section{4.}

Directorium officii Divini pro diaecesi Cracoviensi [...] ad annum Domini MDCCXCVIX [...] conscriptum [...]. Franc[iscus] Cypler, ecclesiarum s. G[eorgii] can[onicus], cath[edralis] vic-dec[anus], [Cracoviae 1798]. Imprimatur: Augustinus Lipiński, vicarius generalis, mpp. $8^{\circ} \mathrm{nlb}$.

Treść: Herb bp. Feliksa Turskiego (Rogala) w środku karty tytułowej wydrukowany czarną farbą. Po obu stronach drzeworytu czarne inicjały tytulatury. Pod nim wiersz na cześć ordynariusza krakowskiego. Główny zrąb rubryceli: „Revolutiones annuae, festa mobilia"; kalendarz liturgiczny na każdy dzień roku; przypomnienie niektórych przepisów liturgicznych; katalog prałatów i kanoników katedry wawelskiej; spis zmarłych w latach 1796-1798 r. duchownych diecezji krakowskiej; „Lunationes”; „Tabula ortus et occa- 
sus solis...". Po każdej składce znajdują się czyste karty na notatki. Właściciel rubryceli poczynił na nich notatki dotyczące wydatków.

Oprawa: tekturowa w kolorze orchowym, z wyciskaną na brzegach podwójną złotą bordiurą o motywach roślinnych i geometrycznych. Na środku okładki wytłoczono złoty ornament roślinny.

Sygn. 44

45.

Directorium officii Divini pro diaecesi Cracoviensi [...] ad annum Domini MDCCC [...] sub felicissimum auspiciis Celsissimi Principis Illusimi, Exlmi, Rndmi Dni Dni Felicis Pauli Turski [...]. Franc[iscus] Cypler, ecclesiarum s. G[eorgii] can[onicus], cath[edralis] vic-dec[anus], [Cracoviae 1799]. $8^{\circ}$ nlb. Po raz pierwszy w tomie znajduje się strona przedtytułowa.

Treść: Herb bp. Feliksa Turskiego (Rogala) w środku karty tytułowej wydrukowany czarną farbą. Po obu stronach drzeworytu czarne inicjały tytulatury. Pod nim wiersz na cześć ordynariusza krakowskiego. Główny zrąb rubryceli: „Revolutiones annuae, festa mobilia"; kalendarz liturgiczny na każdy dzień roku; niewielka reklama książek liturgicznych wydanych przez Uniwersytet Krakowski; przypomnienie niektórych przepisów liturgicznych; katalog prałatów i kanoników katedry wawelskiej; spis zmarłych w 1798 i 1799 r. duchownych diecezji krakowskiej; „Lunationes”; „Tabula ortus et occasus solis...”. Po każdej składce znajdują się czyste karty na notatki. Właściciel rubryceli poczynił na nich notatki dotyczące wydatków. Na wkładce znajduje się podpis właściciela: ks. Walentego Janikowskiego. Na jedynej czystej karcie wklejonej znajduje się notatka o zakupie zegara stołowego oraz informacja o śmierci i pogrzebie bp. F. Turskiego z poczynionym ołówkiem dopiskiem: „Niech mu P. Bóg nie pamięta krzywd które mi poczynił”.

Oprawa: tekturowa w kolorze różowym, z wyciskaną na brzegach podwójną złotą bordiurą o motywach geometrycznych. Na środku okładki wytłoczono złoty ornament roślinny.

Sygn. 45

46.

Directorium officii Divini pro dioecesi Cracoviensi [...] ad annum Domini MDCCCI [...], per Franciscum Cypler, ecclesiar[um] s. G[eorgii] can[onicum], vic-decanum cath[edra]lem Cracovien[siam] conscriptum, Cracoviae [1800], Typis Universitatis. $8^{\circ} \mathrm{nlb}$.

Treść: Główny zrąb rubryceli: „Revolutiones annuae, festa mobilia”; kalendarz liturgiczny na każdy dzień roku; przypomnienie niektórych przepisów liturgicznych; katalog prałatów i kanoników katedry wawelskiej; spis zmarłych w latach 1798-1800 r. duchownych diecezji krakowskiej; dodatek do kalendarz przeznaczony dla dekanatów Bytom i Pszczyna; „Lunationes”; „Tabula ortus et occasus solis...”. W tomiku znajdują się trzy czyste karty, przeznaczone na notatki. Umieszczono na nich informacje o wydatkach. Na wkładce znajduje się podpis właściciela: ks. Walentego Janikowskiego.

Oprawa: tekturowa oklejona amarantową materią, z wyciskaną na brzegach podwójną złotą bordiurą o motywach geometrycznych i roślinnych. Na środku wytłoczono trzy złote korony, herb kapituły krakowskiej.

Sygn. 46 
47.

Directorium officii Divini pro dioecesi Cracoviensi [...] ad annum Domini MDCCCV [...] per Franciscum Cypler, ecclesiar[um] s. G[eorgii] can[onicum], vic-decanum cath [edra]lem Cracovien[siam] conscriptum, Cracoviae [1804], Typis Universitatis. $8^{\circ} \mathrm{nlb}$.

Treść: Główny zrąb rubryceli: „Revolutiones annuae, festa mobilia”; kalendarz liturgiczny na każdy dzień roku; przypomnienie niektórych przepisów liturgicznych; katalog prałatów i kanoników katedry wawelskiej; spis zmarłych w 1803 i 1804 r. duchownych diecezji krakowskiej; dodatek do kalendarza przeznaczony dla dekanatów Bytom i Pszczyna; „Lunationes”; „Tabula ortus et occasus solis...”. Na tylnej wklejce ks. Walenty Janikowski podał spis mieszkańców domu emerytów.

Oprawa: tekturowa czerwona, na brzegach tłoczona podwójna złota bordiura o motywach geometrycznych. Na środku wytłoczono złoty monogramem Chrystusa.

Sygn. 47

48.

Directorium officii Divini [...] pro anno Domini MDCCCVII [...] pro dioecesi Cracoviensi sub felici regimine [...] Andreas Rawa Gawronski [...] conscriptum, per Franciscum Cypler, s. Georgii canonicum, cathedralem vicedecanum, [Cracoviae 1806$] .8^{\circ} \mathrm{nlb}$.

Treść: Herb bp. Andrzeja Gawroński (Rawa) w środku karty tytułowej wydrukowany czarną farbą. Pod nim wiersz na cześć ordynariusza krakowskiego. Główny zrąb rubryceli: „Revolutiones annuae, festa mobilia”; kalendarz liturgiczny na każdy dzień roku; przypomnienie niektórych przepisów liturgicznych; katalog prałatów i kanoników katedry wawelskiej; spis zmarłych w 1805 i 1806 r. duchownych diecezji krakowskiej; „Tabula ortus et occasus solis...". Na jedynej czystej stronie znajdują się notatki właściciela dotyczące wydatków. W przedniej wklejce znajduje się wpis własnościowy ks. Walentego Janikowskiego.

Oprawa: tekturowa oklejona czerwoną materią, z wyciskaną na brzegach bordiurą o motywach geometrycznych. Na środku wytłoczono trzy złote korony, herb kapituły krakowskiej.

Sygn. 48

49.

Directorium officii Divini [...] in annum Domini MDCCCX [...] pro dioecesi Cracoviensi sub felici regimine [...] Andreas Rawa Gawronski [...] conscriptum [...], [Cracoviae 1809]. $8^{\circ} \mathrm{nlb}$.

Treść: Herb bp. Andrzeja Gawrońskiego (Rawa) w środku karty tytułowej wydrukowany czarną farbą. Pod nim wiersz na cześć ordynariusza krakowskiego. Główny zrąb rubryceli: „Revolutiones annuae, festa mobilia”; kalendarz liturgiczny na każdy dzień roku; przypomnienie niektórych przepisów liturgicznych; katalog prałatów i kanoników katedry wawelskiej; spis zmarłych w 1808 i 1809 r. duchownych diecezji krakowskiej; „Phases lunae"; „Tabula ortus et occasus solis...”. Na jedynej czystej stronie znajdują się notatki właściciela dotyczące wydatków. W przedniej okładce znajduje się wpis własnościowy ks. Walentego Janikowskiego.

Oprawa: tekturowa brązowa, na brzegach tłoczona podwójna złota bordiura o motywach geometrycznych.

Sygn. 49 
50.

Directorium officii Divini [...] in annum Domini MDCCCXI [...] pro clero dioeceseos Cracoviensis ex mandato [...] Andreae Rava Gawroński [...] ab Joanne Pysch, vic[edecanum] eccle[iam] cathedra[lem] Cracov[iensiam] editum, Cracoviae [1810]. Typis Mathiae Dziedzicki. $8^{\circ}$ nlb.

Treść: Na drugiej stronie przedtytułu znajduje się herb bp. Andrzeja Gawrońskiego (Rawa) wydrukowany czarną farbą. Pod nim wiersz na cześć ordynariusza krakowskiego. Główny zrąb rubryceli: „Revolutiones annuae, festa mobilia”; kalendarz liturgiczny na każdy dzień roku; przypomnienie niektórych przepisów liturgicznych; katalog prałatów i kanoników katedry wawelskiej; spis zmarłych w 1810 i 1809 r. duchownych diecezji krakowskiej; „Phases lunae”; „Tabula ortus et occasus solis...”. Każda składka kalendarza, poczynając od drugiej, została włożona w czystą składkę folio, przeznaczoną do zapisywania notatek. Karty nie zostały zapisane.

Oprawa: tekturowa czerwona, na brzegach tłoczona złota bordiura o motywach geometrycznych. Na środku niej wytłoczono trzy złote korony, herb kapituły krakowskiej.

Sygn. 50

\section{REFERENCES / BIBLIOGRAFIA}

\section{Źródła drukowane ${ }^{28}$}

„Amtliches Kirchenblatt für die Diözese Culm. Herausgegeben und verlegt von den Bischöflichen General-Vikariat-Atm von Culm", 1 (1858).

„Currenda. De Notificationibus. Konsystorz Biskupi w Tarnowie”, 1 (1851).

„Ex Consistorio Generali Dioecesis Cracoviensis Notificationes ad uniwersum venerabilem clerum tam saecularem quam regularem partis Dioecesos Cracoviensis in civilibus imperio Caesareo Austriaco subjectae", 1 (1863).

„Kronika Diecezji Kujawsko-Kaliskiej”, 1 (1906).

„Miesięcznik Pasterski Płocki”, 1 (1907).

\section{Opracowania}

Alojzy Gonzaga, w: Encyklopedia wiedzy o jezuitach na ziemiach Polski $i$ Litwy, oprac.

L. Grzebień SJ przy współpracy zespołu jezuitów, Kraków 2004, s. 7-8.

Bar Joachim, Polskie procesy kanonizacyjne i beatyfikacyjne, „Ruch Biblijny i Liturgiczny", 11 (1958) nr 11, s. 418-447.

Bar Joachim, Polskie zakony, „Prawo Kanoniczne”, 4 (1961) nr 1-4, s. 421-592.

Bogdziewicz Henryk, Działalność literacka polskiego środowiska pijarskiego $w$ dobie oświecenia, Kraków 2005.

Długosz Józef, Ślązacy uczniami szkoły pijarskiej w Podolińcu na Spiszu, „Śląski Kwartalnik Historyczny. Sobótka”, 30 (1975) nr 2, s. 267-273.

Giner Guerri Severino, San José de Calasanz, Madrid 1985.

Gotkiewicz Marian, Trzy wieki kolegium podolinieckiego (1642-1942), „Nasza Przeszłość", 15 (1962) s. 83-113.

${ }^{28} \mathrm{~W}$ zestawieniu pominięto rubrycele diecezji krakowskiej, których spis znajduje się w publikowanym katalogu. 
Hadamik Czesław, Kościót Wizytek $w$ Lublinie $w$ świetle ratowniczych badań archeologicznych w 2010 roku, „Wiadomości Konserwatorskie”, (2011) nr 30, s. 58-70.

Ignaszewska Franciszka S., Historia fundacji klasztoru SS. Nawiedzenia NMP (Wizytek) w Krakowie (1681-1699), „Nasza Przeszłość”, 58 (1983) s. 5-93.

Janicki Jan J., Błogosławiony Wincenty Kadtubek - nauczyciel miłości Boga i Ojczyzny, w świetle tekstów liturgicznych i nauczania Kościoła, „Kieleckie Studia Teologiczne”, 9 (2010) s. 35-60.

Kamczyk Wojciech, Kult świętego Szczepana w duszpasterstwie biskupa Augustyna z Hippony, „Śląskie Studia Historyczno-Teologiczne”, 49 (2016) z. 2, s. 311-331.

Kaźmierczyk Adam, Rodziłem się Żydem... Konwersje Żydów w Rzeczypospolitej XVII-XVIII wieku, Kraków 2015.

Kościół i społeczeństwo Małopolski w II połowie XVIII w. Materiały źródłowe, t. 1: Ludność i organizacja diecezji krakowskiej, oprac. B. Szady, Lublin 2010.

Kościól i społeczeństwo Małopolski w II połowie XVIII w. Materiaty źródłowe, t. 2: Duchowieństwo diecezji krakowskiej, oprac. J. Szczepaniak, Lublin 2010.

Kracik Jan, Post po staropolsku, „Nasza Przeszłość”, 75 (1991) s. 65-90.

Krucki Łukasz, Katalogi rubrycel i schematyzmów zakonów oraz zgromadzeń zakonnych przechowywanych $w$ księgozbiorze podręcznym Archiwum Archidiecezjalnego w Gnieźnie (1767-2008), „Hereditas Monasteriorum”, 6 (2015) s. 343-396.

Kuczkowski Mirosław, Św. Jan z Dukli w świetle polskich czasopism tercjarskich (19181939), „Roczniki Teologiczne”, 51 (2014) z. 4, s. 151-181.

Kumor Bolesław, Ustrój i organizacja Kościoła polskiego w okresie niewoli narodowej (1772-1918), Kraków 1980.

Kupisiński Zdzisław, Kult świętej Barbary w polskiej religijności ludowej, „Roczniki Teologii Fundamentalnej i Religiologii”, 4 (59) (2012) s. 242-257.

Litak Stanisław, Atlas Kościoła łacińskiego w Rzeczypospolitej Obojga Narodów w XVIII wieku, Lublin 2006.

Mróz Franciszek, Sanktuaria i kaplice Bożego Grobu w Polsce, „Peregrinus Cracoviensisi”, 8 (2000) s. 79-114.

Pitala Adam, Kolegium pijarów w Krakowie (szkic historyczny), „Nasza Przeszłość”, 15 (1962) s. 51-81.

Poleszak Leszek, Zarys historii kultu Najświętszego Serca Pana Jezusa na przestrzeni ostatnich stuleci, w: Zawierzyć Sercu Jezusa, red. W. Kubik, Kraków 2011, s. 31-51.

Postek Sławomir, Dzieje szkoły pijarskiej w Łukowie 1701-1833, „Analecta: studia i materiały z dziejów nauki”, 5 (1996) nr 2 (10), s. 141-169.

Rozynkowski Waldemar, Św. Barbara i Barbarka - wokół początków kultu świętej męczennicy, w: Św. Barbara i Barbarka, red. W. Rozynkowski, W. Miszewski, Toruń 2005, s. 9-21.

Sitnik Aleksander K., Święty Jan z Dukli, „Folia Historica Cracoviensia”, 15-16 (20092010) s. 111-126.

Słoma Ireneusz, 250 lat liturgicznego kultu Serca Jezusowego w Polsce-Memoriał biskupów polskich z 1765 roku, „Roczniki Teologiczne”, 62 (2015) z. 8, s. 145-158.

Soboń Marcin, Od wspólnoty charyzmatycznej do grupy interesów: przypadek frankizmu, „Czasy Nowożytne”, 16 (2004) s. 92-115.

Soto Artuñeda Wenceslao, Celebraciones por las canonizaciones de jesuitas en el Colegio de Málaga en la Edad Moderna, „Revista de historia moderna. Anales de la Universidad de Alicante", (2003) nr 21, s. 141-164.

Starnawska Maria, Kult św. Piotra w Polsce średniowiecznej na tle europejskim, „Ecclesia. Studia z Dziejów Wielkopolski”, 6 (2011) s. 25-35. 
Szczepaniak Jan, Najstarsze spisy duchowieństwa diecezji krakowskiej, „Folia Historica Cracoviensia", 11 (2005) s. 157-359.

Szczepaniak Jan, Duchowieństwo diecezji krakowskiej w XVIII wieku. Studium prozopograficzne, Kraków 2010.

Szczepaniak Jan, Nekrologium. Księża diecezji krakowskiej zmarli w latach 1749-1810, Kraków 2010.

\title{
CONTENTS AND THE CATALOGUE OF THE DIRECTORIES OF THE DIOCESE OF KRAKOW FROM THE YEARS 1735-1811 FROM THE REFERENCE LIBRARY OF THE ARCHIVES OF THE METROPOLITAN CURIA IN KRAKOW
}

\begin{abstract}
The Archives of the Metropolitan Curia in Krakow hold a significant collection of the Krakow diocese's liturgical calendars. From the first half of the 18th century, only three copies have survived (1735, 1738, and 1745). Beginning with 1750 , the collection is almost complete. Only 9 volumes are missing, from the years: $1753,1754,1755,1756,1775,1779,1781,1784,1789$, and 8 from the beginning of the 19th century: 1802-1804, 1806, 1808-1810, 1839. Due to the widespread use of the calendar by priests, the following items were added to the directories: information on services and practices peculiar to the diocese, orders of the clergy and secular authorities (especially regarding changes in liturgical and fasting regulations). Until the last decades of the 19th century, there were no rules for editing the appendices to the directories. Some volumes include numerous detailed liturgical regulations, as well as messages, ordinances and short letters to the clergy that have not been published anywhere else. Others do not contain even the new and important regulations and orders for the priests. These appendices are a valuable resource for historians, albeit rarely used due to a small number of preserved copies and the lack of description of the contents, which necessitates a lengthy query. The publication of the catalogue of the Krakow directories is intended to provide help in finding information that may prove useful for a historian.
\end{abstract}

Keywords: liturgical calendars (directories), Krakow diocese, clergy schematisms (catalogues), liturgical regulations, Catholic enlightenment 